\title{
The ancestry and magmatic evolution of Archaean TTG rocks of the Quadrilátero Ferrífero province, southeast Brazil
}

\author{
Cristiano Lana ${ }^{\mathrm{a}, *}$, Fernando F. Alkmim ${ }^{\mathrm{a}}$, Richard Armstrong ${ }^{\mathrm{b}}$, Ricardo Scholz ${ }^{\mathrm{a}}$, Rafael Romano ${ }^{\mathrm{a}}$, \\ Herminio A. Nalini Jr. ${ }^{a}$ \\ a Departamento de Geologia, Escola de Minas, Universidade Federal de Ouro Preto, Morro do Cruzeiro, 35400-000 Ouro Preto, MG, Brazil \\ ${ }^{\mathrm{b}}$ Research School of Earth Sciences, The Australian National University, Canberra 0200, ACT, Australia
}

\section{A R T I C L E I N F O}

\section{Article history:}

Received 14 January 2013

Received in revised form 18 March 2013

Accepted 19 March 2013

Available online 1 April 2013

\section{Keywords:}

Archaean

Quadrilátero Ferrífero

TTG

LA-ICP-MS and SHRIMP geochronology

São Francisco Craton

\begin{abstract}
A B S T R A C T
Combined LA-ICP-MS and SHRIMP U-Pb ages from Quadrilátero Ferrífero (QF) province reveals for the first time three main periods of TTG magmatism in the southern part of the São Francisco Craton (Brazil). These periods - described here as the Santa Barbara (SB), Rio das Velhas I (RVI) and Rio das Velhas II (RVII) events - embody a significant part of a protracted tectonomagmatic history of the Craton, spanning from 3220 to $2770 \mathrm{Ma}$. The initial stages of TTG magmatism (the SB event) led to formation of a core of Palaeoarchaean TTG crust via magmatic additions of juvenile felsic rocks into mafic-ultramafic rocks, at ca. 3212-3210 Ma. The following event (RVI event) saw the growth of this Palaeoarchaean core into a more composite, polydefomed continental segment through magmatic additions of juvenile TTG rocks and tectonic accretion of mafic-ultramafic greenstone belt terrains. Our $\mathrm{U}-\mathrm{Pb}$ data and regional constraints suggest that much of the TTG crust exposed in the QF region today was produced during the RVI event, between 2930 and $2900 \mathrm{Ma}$. The final stages of TTG crust production (RV II event) were marked by convergence-related magmatism, affecting an extensive Palaeo- to Mesoarchaean continental block (The RVI block). The timing and duration of the latest TTG event coincides with the felsic volcanism and deposition of turbiditic wackes of the main greenstone belt sequence.
\end{abstract}

(C) 2013 Elsevier B.V. All rights reserved.

\section{Introduction}

The Quadrilátero Ferrífero (QF) province, in the Southern São Francisco Craton, exposes a large segment of Palaeo- to Neoarchaean continental crust that served for many years as type locality for understanding early crustal evolution in South America (Figs. 1 and 2) (e.g., Teixeira and Figueiredo, 1991; Machado and Carneiro, 1992; Machado et al., 1992, 1996; Teixeira et al., 1996; Carneiro et al., 1997; Noce et al., 1998, 2005; Hartmann et al., 2006; Romano et al., 2013). The Archaean history of this segment spans about $600 \mathrm{My}$, and can be subdivided into two fundamentally distinct stages. The first stage, lasting more than $400 \mathrm{My}$, involved the emplacement of voluminous Tonalite-Trondjhemite-Granodiorite (TTG) magmas and extrusion of mafic and ultramafic rocks between 3200 and $2770 \mathrm{Ma}$ (e.g., Teixeira et al., 1996). The TTG magmatism led to the construction of a regionally extensive sialic crust containing several greenstone belt occurrences (e.g., Teixeira et al., 1996). The second stage was marked by high-grade ductile deformation, partial melting of the TTG-greenstone crust, and concomitant

\footnotetext{
* Corresponding author. Tel.: +55 3135591848.

E-mail addresses: cris.lana@pq.cnpq.br, cristianodeclana@gmail.com (C. Lana).
}

emplacement of voluminous potassic granitoids between 2750 and $2600 \mathrm{Ma}$ (Machado et al., 1992; Teixeira et al., 1996; Campos et al., 2003; Romano et al., 2013). This period of intra-crustal melting saw the emergence of a stable continental platform that was rigid enough to sustain the deposition of thick Palaeoproterozoic sequences, including extensive banded iron formation units of the QF mining district (Romano et al., 2013).

Specifically for the TTG rocks, limited zircon U-Pb TIMS data suggest that the main TTG magmatism was coeval with extrusion of several felsic volcanic units of the main greenstone belt (the Rio das Velhas Greenstone Belt) between 2770 and $2780 \mathrm{Ma}$ (Machado et al., 1992; Noce et al., 1998). The age dataset, together with previous Sm-Nd TDM model ages, also indicate that this magmatic event involved partial melting of sialic crust older than $3000 \mathrm{Ma}$ (Carneiro et al., 1997; Teixeira et al., 1996). However, U-Pb zircon age data from the earliest TTG rocks, which could provide clues to the first emergence of continental crust, have not been fully explored. The $>3000 \mathrm{Ma}$ ancestry of the TTG crust is mainly indicated by $\mathrm{Rb}-\mathrm{Sr}$ and $\mathrm{Pb}-\mathrm{Pb}$ model ages (Teixeira et al., 1996) and indirectly via detrital zircon ages from the greenstone belt rocks and overlying supracrustal sequences (Machado et al., 1992, 1996; Noce et al., 2005; Hartmann et al., 2006). The detrital age dataset is characterized by main peaks at 2700-2730 Ma, 2770-2800 Ma and $2900 \mathrm{Ma}$, 


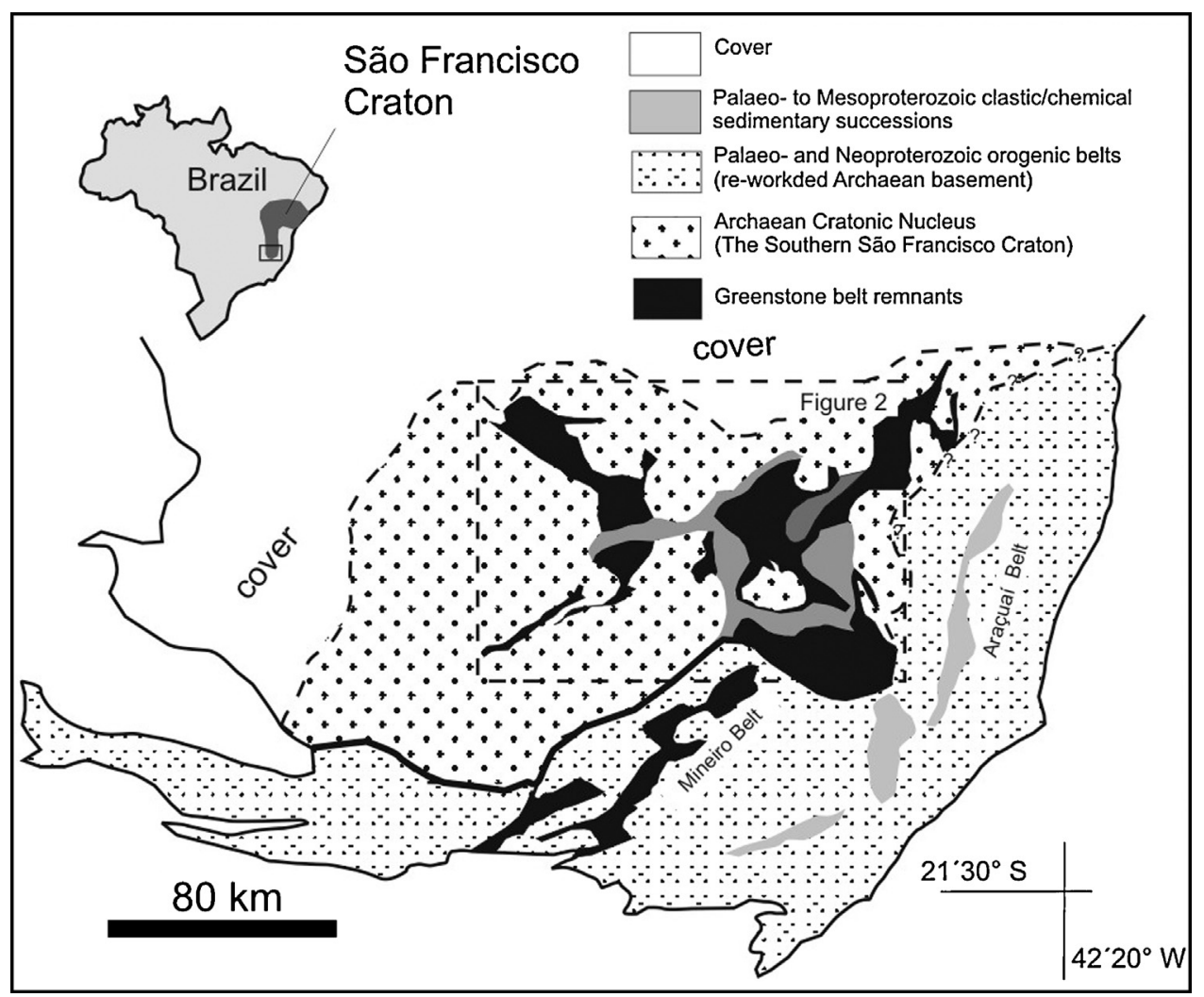

Fig. 1. Simplified map of the Southern São Francisco Craton showing the main Palaeo- to Neoarchaean terrain and adjacent Proterozoic belts.

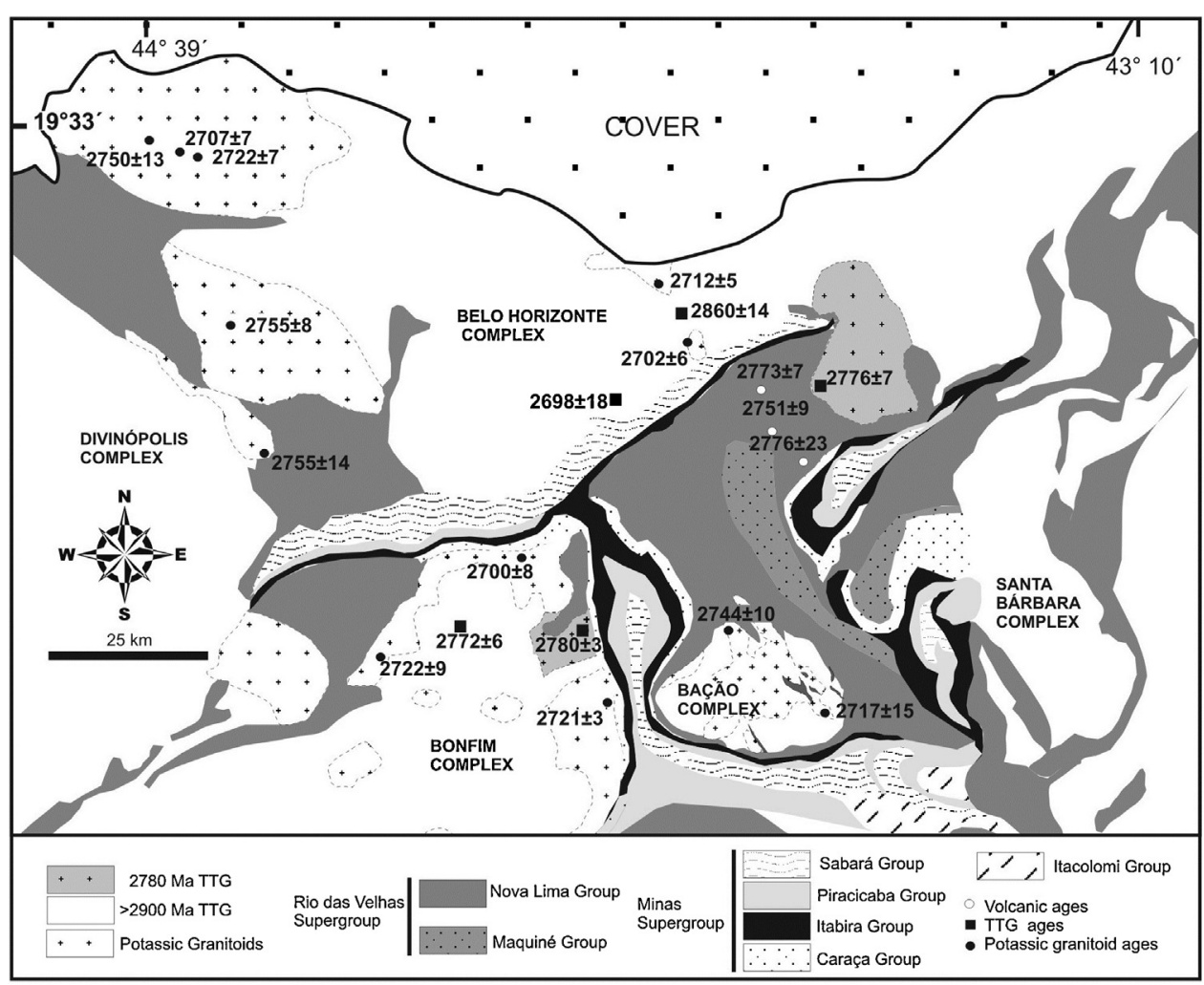

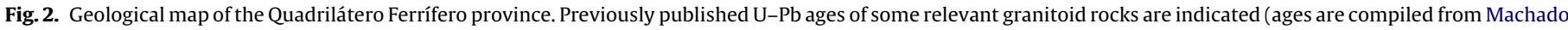
et al., 1992; Machado and Carneiro, 1992; Romano, 1989; Noce et al., 1998; Romano et al., 2013). 
and a minor subset of grains recording older ages from $3200 \mathrm{Ma}$ to $3800 \mathrm{Ma}$. Evidence for TTG crust older than $2780 \mathrm{Ma}$ is limited to sporadic samples in the ca. $25,000 \mathrm{~km}^{2}$ of the Quadrilátero Ferrífero and surrounding gneiss-granitoid terrains (Fig. 2). Significantly, changes in magmatic regime that potentially occurred in the Archaean are difficult to observe because of the complex and protracted history of these TTG rocks.

Field observations combined with high resolution zircon $\mathrm{U}-\mathrm{Pb}$ age data from the TTG rocks would place important constrains on the timing of the magmatism, deformation and metamorphism in the southern part of the São Francisco Craton. This would lead to a much richer understanding of the process occurring during construction of one of the oldest segments of continental crust in South America. In this paper, a number of new SHRIMP and LA-ICP-MS zircon $\mathrm{U}-\mathrm{Pb}$ ages ( 14 samples) are combined with published $\mathrm{U}-\mathrm{Pb}$ age data to provide a comprehensive dataset for the ages of the TTG crust in the Southern part of the São Francisco Craton. We aim to constrain the ancestry and the main pulses of TTG magma production across the entire province, and to place the periods of TTG production into a broader geodynamic context that may highlight the processes of Archaean crustal growth in South America.

\section{Regional geology}

The stratigraphic framework of the QF comprises two main components: amphibolite-facies granitoid-gneiss complexes, and a polydeformed, low-grade supracrustal sequence. The cover succession includes Archaean rocks of the Rio das Velhas Supergroup and Palaeoproterozoic metasedimentary sequences of the Minas Supergroup and the Itacolomi Group (Dorr et al., 1957; Dorr, 1969).

The Rio das Velhas Group is subdivided into Nova Lima and Maquiné Groups (Dorr, 1969). The early work by Ladeira (1980) and Zucchetti et al. (2000a,b), Baltazar and Zucchetti (2007) attribute the onset of the Rio das Velhas to extrusion of massive komatiites to pillowed komatiitic basalts. The massive komatiites are characterized by spinifex textures, layers with cumulus olivine/intercumulus orthopyroxene and a level of lahar-type breccia (Zucchetti et al., 2000a,b). The pillowed units are intercalated with chemical carbonaceous sediments, consistent with a submarine environment for the volcanism (Schrank et al., 1990). This period of mafic volcanism and carbonate precipitation was followed by submarine deposition of pelites, banded iron formation and subordinate cherts, which are in turn capped with a volcanoclastic sequences of conglomerate-graywacke, sandstonegraywacke and pelite-graywacke. Three felsic volcanic events mark the final deposition of the Nova Lima Group at ca. $2792 \pm 11$, $2773 \pm 7$ and $2751 \pm 9 \mathrm{Ma}$ (Machado et al., 1992, 1996; Noce et al., 2005). Overlying the Nova Lima Group is a $2000 \mathrm{~m}$ thick clastic unit of marine and fluvial sediments of the Maquiné Group. According to Dorr (1969) this group comprises a flysch to molasse-type sequence, consisting of a coarsening upward succession of wackes that also became cleaner (more quartz rich) and conglomeratic towards the top. Contact relationships between the Nova Lima and Maquiné are often overprinted by fault zones, but gradational and discordant contacts have been observed (Dorr, 1969, and references therein). Although limited, the available detrital zircon $\mathrm{U}-\mathrm{Pb}$ age data suggest that a continental block ranging in age from 3260 to 2877 Ma was the main source of the Maquiné sediments (e.g., Machado et al., 1996).

The Minas Supergroup was deposited over the Rio das Velhas Supergroup and the granitoid-gneiss terrain (Fig. 2). It is subdivided into the Tamanduá, Caraça, Itabira, Piracicaba and Sabará Groups (Dorr, 1969). The Tamanduá and Caraça Groups, at the base of the Supergroup, are made up of alluvial sandstones, conglomerates, and shales that grade upward into coastal marine pelites (Dorr,
1969; Renger et al., 1995; Alkmim and Martins-Neto, 2012). Zircon U-Pb detrital age data suggest that the Caraça and Tamanduá sediments derived predominantly from erosion of TTG and potassic granitoid sources and that the maximum age of deposition is ca. 2600 Ma (Machado et al., 1996; Hartmann et al., 2006). The sedimentation of the Caraça shallow-water pelites was followed by a major transgression that records a period of chemical sedimentation. This event led to the accumulation of the marker bed of the QF, the Lake Superior-type Cauê Banded Iron Formation, and was subsequently followed by the deposition of ca. $2400 \mathrm{Ma}$ stromatolite-rich carbonates (Dorr, 1969; Babinski et al., 1995). The carbonates are in contact with marine sandstones and pelites of the Piracicaba Group. This unit records a similar zircon U-Pb detrital age to the Caraça Group and most probably was derived from erosion of the TTG and potassic granitoids of the QF basement (Machado et al., 1996). The stratigraphy of the Minas sequence is completed by the Sabará Group. The Sabará Group comprises a thick pile of turbidites, volcanic tuffs, and diamictites derived from much younger 2100 Ma sources (Dorr, 1969; Renger et al., 1995; Machado et al., 1996).

The Itacolomi Group is the youngest unit in the QF supracrustal sequence. The Group comprises an up to $2000 \mathrm{~m}$-thick pile of alluvial sediments that is separated from the Minas Supergroup by a regional unconformity. While the Minas sedimentary rocks are portrayed as passive margin to syn-orogenic deposits that record the operation of a Wilson cycle along the southern margin of the São Francisco Craton, the Itacolomi Group is viewed as an intermontane molasse accumulated during the collapse phase of the Rhyacian orogeny (Marshak et al., 1992; Alkmim and Marshak, 1998; Alkmim and Martins-Neto, 2012).

\subsection{The granitoid-gneiss complexes}

The granitoid-gneiss complexes of the QF, on which this study is focused, are exposed in the core of domal structures such as the Bação, Belo Horizonte, Caeté, Santa Bárbara, and Bonfim (Fig. 2). The domes expose several phases of TTG gneisses and plutons, which are in turn intruded by voluminous sheets and bodies of potassic granitoids (Fig. 2). The TTG assemblage range from hornblende + biotite + plagioclase + quartz tonalites to plagioclase + K-feldspar + biotite + quartz granodiorites (Carneiro, 1992; Noce, 1995; Endo, 1997). These rocks record a period of high-grade metamorphism, with formation of a penetrative amphibolite-facies foliation and local development of banded/stromatic migmatites (Carneiro, 1992; Noce, 1995; Endo, 1997). This foliation underwent a complex succession of folding and refolding, which testify to the polyphase deformation history of Archaean rocks in the Southern São Francisco Craton.

Exposures of the Belo Horizonte, Bação, Bonfim and Santa Bárbara complexes show a number of different trondhjemitic phases with well-preserved intrusive relationships. Moreover, all these complexes are characterized by the presence of metre to kilometrescale greenstone remnants that are in tectonic contact with the TTG bodies (e.g., Figs. 2 and 4). Both TTG and greenstones record similar polyphase deformation histories. The complex foliation pattern is in striking contrast with the commonly smooth, and, in most places, low metamorphic grade foliation trajectories observed in the overlying Palaeoproterozoic supracrustal sequence (e.g., Alkmim and Marshak, 1998). The gneisses are intruded by comparatively small, 2780-2770 Ma TTG plutons, which are known as the Caeté Trondhjemite and Samambaia Tonalite (e.g., Machado and Carneiro, 1992; Machado et al., 1992), in the Caeté and Bonfim complexes respectively (Fig. 2). These younger trondhjemite phases are less abundant and are distinguished from the older gneisses by their more massive, undeformed nature, lacking a penetrative planar fabric. Likewise, granitoids of the younger 2750-2600 Ma potassic 
granitoid suite, widely distributed across Southern São Francisco Craton (Romano et al., 2013), are significantly less deformed than the TTG phases. This structural contrast between the TTG gneisses and younger granitoids is a clear indication that the tectonic climax with multiple TTG magmatism and polyphase high-grade deformation in the Southern São Francisco Craton occurred prior to 2750-2770 Ma.

Previous zircon U-Pb TIMS data indicate a range in ages from 2920 Ma to $2772 \mathrm{Ma}$ for the TTG assemblage. Early zircon U-Pb TIMS work by Machado and Carneiro (1992) in the Bonfim TTG gneisses identified two subconcordant zircon populations with apparent ages of ca. 2920 Ma and 2770 Ma. Noce et al. (1998) obtained a zircon $\mathrm{U}-\mathrm{Pb}$ upper concordia intercept TIMS age of $2860 \pm 14$ Ma from a migmatite in the Belo Horizonte dome. This intercept age was interpreted to reflect the timing of the oldest yet recognized high-grade metamorphism and partial melting of $>2900$ Ma TTG crust. However, this age was based on a limited number of highly discordant grains (Fig. 2). The only two ages that were substantially accurate and precise were obtained from the 2772-2778 Ma Caeté and Samambaia granitoids. These ages overlap within error with ages from the volcanic rocks in the Archaean supracrustal sequence of the QF (Machado et al., 1992; Noce et al., 2005).

The Archaean TTG rocks were subsequently intruded by numerous 2750 and $2700 \mathrm{Ma}$ potassic granitoids that form $\mathrm{km}$-scale batholiths or thick granitoid sheets around the margins or in the interior of the complexes (Figs. 2 and 3). Recent zircon U-Pb age data indicates that this granitoid event marked the stabilization of the TTG crust and the development of a rigid cratonic nucleus (The Southern São Francisco Craton - Fig. 1) that supported the development of the supracrustal rocks of the QF. Outside this Archaean block, the crystalline and supracrustal rocks to the south and east of the QF were affected by two Proterozoic orogenic systems. For instance, the southern margin of QF (Fig. 1) is bounded by a km-wide, arcuate corridor of high-grade, polydeformed Archaean TTG rocks, elongated greenstone belt remnants and numerous 2300-2000 Ma granitoids phases (Teixeira and Figueiredo, 1991; Alkmim and Marshak, 1998; Machado et al., 1996; Teixeira et al., 1996, 2000; Noce, 1995; Teixeira et al., 2008). Known as the Mineiro Belt, this corridor developed as a consequence of plate convergence and collision along the margin of the Archaean core of the São Francisco Craton during the 2100 Ma Transamazonian event. Similarly, the eastern margin of the province was affected by the 600-500 Ma Araçuaí orogeny (Almeida et al., 1981; Pedrosa-Soares et al., 2001; Alkmim et al., 2006), during the assembly of West Gondwana by the end of the Neoproterozoic (the Brasiliano event).

\section{Geochronology}

In order to record the full spectrum of the TTG magmatic events in the southern part of the São Francisco Craton, we collected 14 samples from the main crystalline complexes around the Quadrilátero Ferrífero area, including the Belo Horizonte, Bação, Bonfim and Santa Bárbara complexes as well as one TTG sample from the Mineiro Belt. The selection of a large number of samples is justified because it was not always possible to correlate the various TTG units based on field relationships, mineralogy and petrography. Thus, the sampling protocol was aimed at obtaining a substantial amount of $\mathrm{U}-\mathrm{Pb}$ age data (of the magmatic phases) over an extensive area of TTG crust.

The TTG samples contained zircon grains that range from slightly hazy to milky and opaque (Fig. 3). Such characteristics are usually attributable to zones of high uranium that have undergone alteration. According to Machado et al. (1992) and Machado and Carneiro (1992), zircons from the TTG rocks in the QF are largely altered and rich in mineral inclusions (Fe-oxides). The white to milky grains are observed in both magnetic and non-magnetic fractions, but non-magnetic fractions yielded subfractions that were somewhat translucent to partly translucent grains. A close inspection of the partly translucent grains revealed that the cores were usually better preserved than the rims. Machado et al. (1992) also observed that the majority of the milky white grains were fragile and would disintegrate instantly during air abrasion. This is likely a result of intense chemical weathering and leaching of the U-rich areas within the grains. Likewise, our previous experience with these zircons (e.g., Romano et al., 2013) shows that the milky white grains did not cope well with the laser (during the ablations), because of their poorly preserved crystalline structure (i.e., most of these grains were quickly pulverized and yielded unreliable $\mathrm{U}-\mathrm{Pb}$ data).

In this study, only the translucent and partly translucent grains were selected for SHRIMP and LA-ICP-MS analysis. The SHRIMP and LA-ICP-MS analysis were carried out at the Australian National University and Universidade Federal de Ouro Preto, respectively. See Appendix for details on the methodology and instrumentation. The results of the SHRIMP and LA-ICP-MS analyses of samples and secondary standards can be found in Electronic Supplement. The LA-ICP-MS and SHRIMP data were reduced using the ISOPLOT/SQUID program (Ludwig, 2001a,b) with ages calculated and plotted on Concordia diagrams using the IsoplotEx 2.46 program. Uncertainties given for individual analyses (ratios and ages) are at the 1 sigma level. All uncertainties in the calculated intercept or Concordia ages are reported at 2 sigma confidence limits, unless stated otherwise. For the probability density diagrams and histograms, the Age Display set of Excel ${ }^{\mathrm{TM}}$ macros were used (Sircombe, 2004).

\subsection{Results}

\subsubsection{Bação complex}

Located in the central part of the QF (Fig. 2), the $25 \mathrm{~km}$-wide Bação dome exposes a crystalline complex that predominantly consists of potassic granitoids and TTG rocks. A number of greenschistto amphibolite-facies greenstone belt remnants are found in the eastern portion of the dome (Fig. 4a). The TTG rocks are especially well exposed on the periphery of the dome, and are characterized by the alternation of trondhjemitic and tonalitic bands. Locally, these bands are crosscut by potassic granitoid sheets that are intruded predominantly parallel or subparallel to the gneissosity. Previous studies have dated two samples of potassic granitoids at $2744 \pm 10 \mathrm{Ma}$ and $2717 \pm 5 \mathrm{Ma}$ (Fig. 4a), consistent with the main potassic magmatic episodes between $2700 \mathrm{Ma}$ and $2750 \mathrm{Ma}$ (Romano et al., 2013). In this study, we obtained ages of eight samples of TTG's spread across the dome (Samples D04, D06, D7A, D7B, MP-1, SG-1, SG-2 and D12). Refer to Electronic Supplements for results of individual SHRIMP and LA-ICP-MS analyses.

Sample D06 (UTM: 628831/7748456) was extracted from a banded trondhjemite, exposed along railway cuttings in the southcentral part of the Bação dome, a few kilometres from Engenheiro Correia (Fig. 4a). The rock displays a strong vertical foliation defined by biotite and quartz aggregates, and $\mathrm{mm}$-wide leucocratic (plagioclase + quartz) bands (Fig. 4b). Locally, the foliation is accentuated by elongated ( $\mathrm{cm}$-long) biotite-amphibolite enclaves. Zircons from this sample are generally stubby, with round terminations and range in colour from light to dark brown. CL-images reveal complex internal structures with rather bright cores surrounded by dark, structureless overgrowths. The zircon cores are generally round, show resorbed rims, and preserve some oscillatory zoning (Fig. 3). SHRIMP analyses on eight of these cores gave concordant to subconcordant points (1-8\% discordant) with apparent ages of ca. $2900 \mathrm{Ma}$ A regression through these points define a Pb-loss Discordia with 

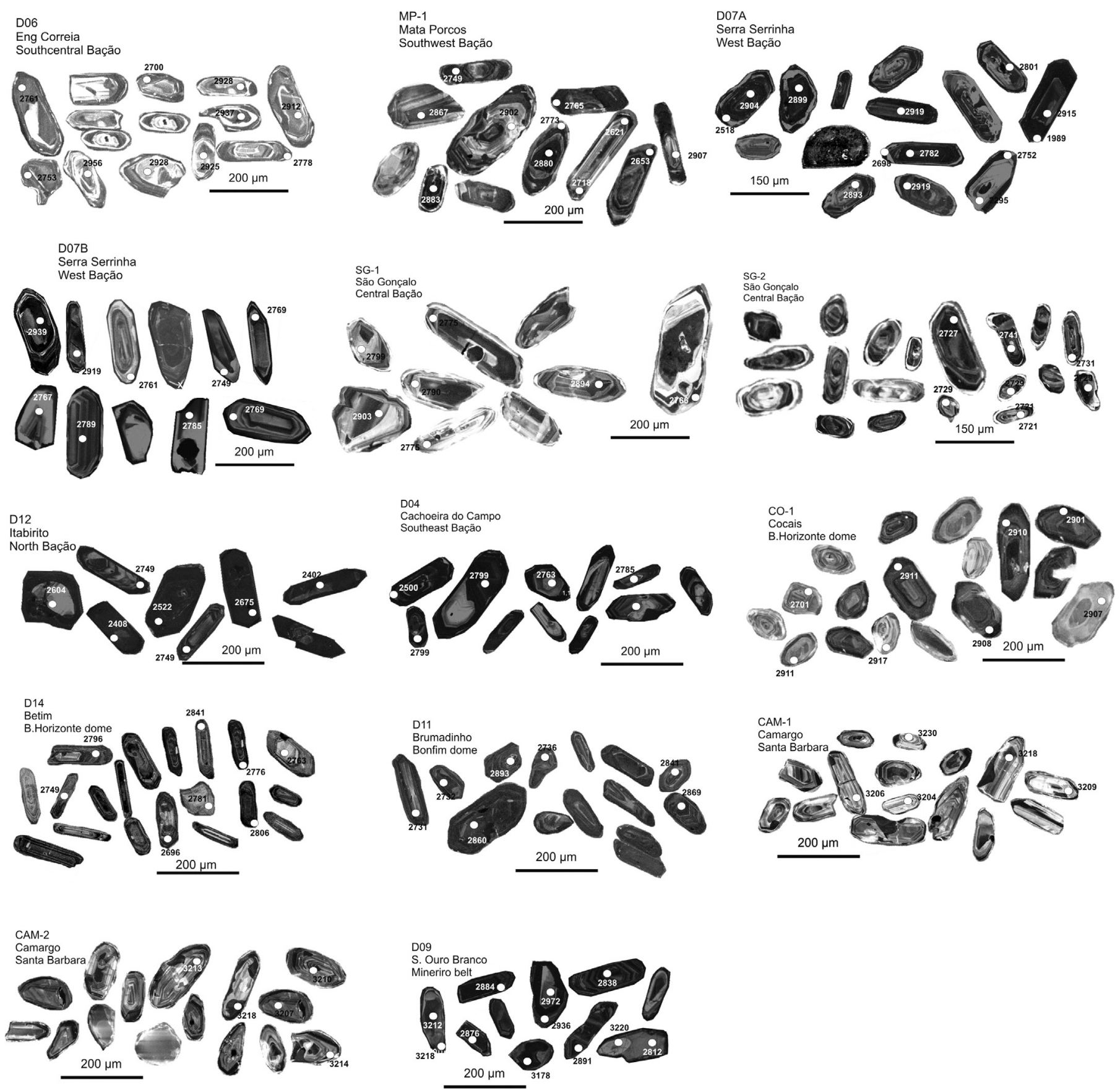

Fig. 3. Cathodoluminescence images of zircons analyzed in this study.

an upper intercept age of $2925 \pm 8 \mathrm{Ma}(\mathrm{MSWD}=0.67)$ (Fig. 5a). This age is interpreted as the crystallization age of the sample. Three other analyses on fairly altered cores gave discordant points with large internal errors - these analyses were discarded. Analyses of the structureless dark overgrowths gave points with rather younger apparent ages than those in the magmatic cores. They were also marked by low $\mathrm{Th} / \mathrm{U}$ ratios, which could characterize them as metamorphic overgrowths or recrystallization domains. They define a $\mathrm{Pb}$-loss Discordia line with a lower intercept of $429 \pm 15 \mathrm{Ma}$ and upper intercept of $2794 \pm 15 \mathrm{Ma}(\mathrm{MSWD}=3.1$ ) (Fig. $5 \mathrm{a})$.

Sample MP-1 (UTM: 622543/7747051) comes from a trondhjemitic gneiss that is exposed in the southwestern periphery of the dome, near Mata Porcos stream (Fig. 4a). This rock records a strong vertical gneissosity defined by oriented biotite and $\mathrm{cm}$-wide leucocratic bands. Locally, the gneiss is intruded by undeformed, layer-parallel leucogranite bands (Fig. 4c). Similar to Sample D06, this sample contained zircons that are round to stubby, with round terminations and range in colour from light pink to brown. They have concentrically zoned, CL-bright cores surrounded by dark structureless rims. The cores range from round to irregular and may show resorbed rims (Fig. 3). LA-IPM-MS analyses of the least altered cores gave concordant to highly discordant points that plot along a Pb-loss line with upper intercept age of $2903 \pm 12 \mathrm{Ma}$ (MSWD = 3.2). The structureless rims were relatively more altered relative to the core. A large number of spot analyses on the altered, milky white rims yielded unreliable $\mathrm{U}-\mathrm{Pb}$ ratios (due to discordancy) were discarded. Only seven of these points, placed on somewhat pristine areas of the grains, gave a Discordia line with an 


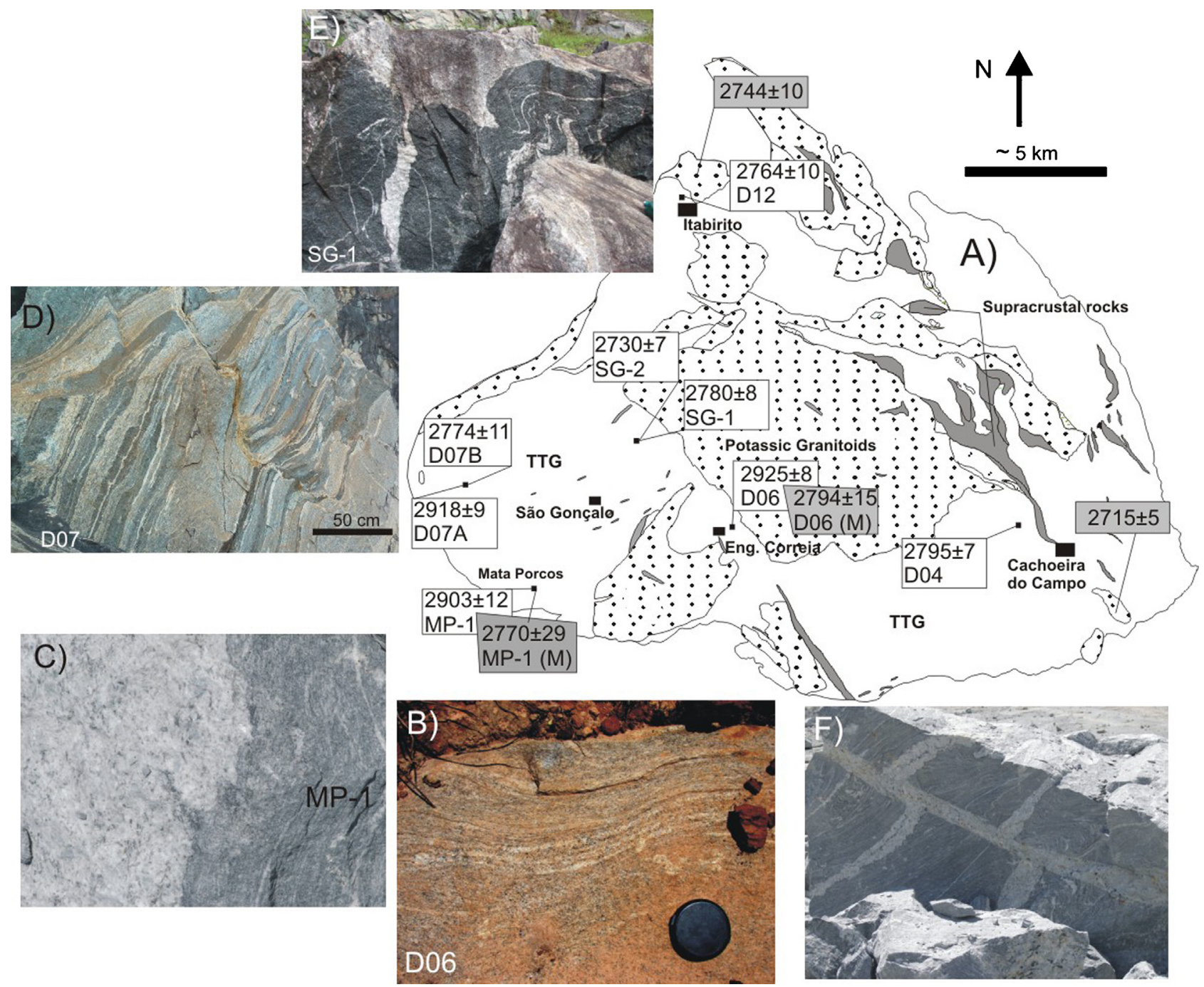

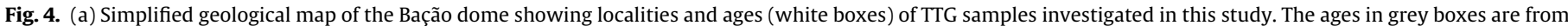

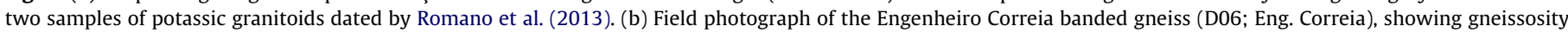

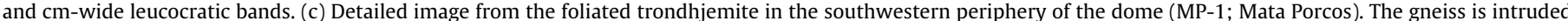

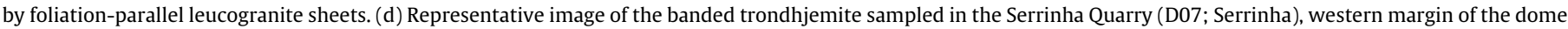

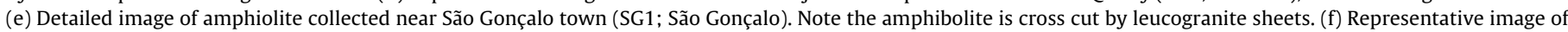

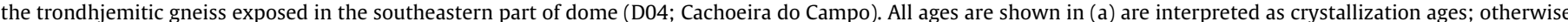
labelled as (M) for metamorphic age.

upper concordia intercept age of $2770 \pm 29 \mathrm{Ma}(\mathrm{MSWD}=4.2$ ). This age is identical (within error) to the metamorphic age obtained for the Engenheiro Correia gneiss (Sample D06). We suggest that this sample crystallized at $2903 \pm 12 \mathrm{Ma}$ and experienced a metamorphic event at $2770 \pm 29 \mathrm{Ma}$.

Samples D07A and D07B (UTM: 620152/7749497) were collected in a quarry outcrop (Serrinha Quarry) in the southwestern portion of the Bação dome (Fig. 4a). The quarry exposes strongly banded, light coloured trondhjemite gneiss that records a vertical compositional banding (Fig. 4d). Both biotite and plagioclase-rich bands are locally intruded by numerous leucogranite sheets that vary in width from several millimetres to a few metres. Sample D07A was extracted from a homogenous trondhjemite gneiss, which is interpreted to be oldest phase of the TTG gneiss in this quarry. Zircons from this sample are prismatic to stubby, with round terminations, ranging in length from 100 to $200 \mu \mathrm{m}$. CLimages reveal complex core and rim structures (Fig. 3). Most grains show irregular cores, surrounded by dark or bright structureless rims. SHRIMP spot analyses on twelve of the cores gave subconcordant to concordant points, plotting along a Pb-loss Discordia that intercepts the upper concordia at $2918 \pm 9$ Ma $(M S W D=1.6$ ) (Fig. 5c). Twelve analyses on the structureless rims gave very discordant points, with substantially younger apparent ${ }^{207} \mathrm{~Pb} /{ }^{206} \mathrm{~Pb}$ ages of ca. 2600-2780 Ma. A regression line through these analyses intercept the Concordia at $661 \pm 110 \mathrm{Ma}$ and $2775 \pm 39 \mathrm{Ma}$ $(\mathrm{MSWD}=8.8$ ) (Fig. 5c). Our interpretation is that this rock crystallized at ca. $2918 \pm 10 \mathrm{Ma}$ and was metamorphosed at around $2775 \mathrm{Ma}$.

Sample D07B was extracted from a $50 \mathrm{~cm}$ wide mediumgrained, leucocratic band of the TTG gneiss. This band crosscuts the trondhjemite gneiss, but locally it is intruded parallel to the main foliation. Zircons from this sample are prismatic, ranging in length from 50 to $200 \mu \mathrm{m}$. CL-images reveal internal oscillatory zoning (Fig. 3). A few grains showed complex, structureless cores surrounded by oscillatory rims. SHRIMP analyses on the oscillatory overgrowth grains gave apparent ${ }^{207} \mathrm{~Pb} /{ }^{206} \mathrm{~Pb}$ ages of 2600 and $2800 \mathrm{Ma}$. Thirteen of the most concordant to subconcordant points give a precise ${ }^{207} \mathrm{~Pb} /{ }^{206} \mathrm{~Pb}$ age of $2774 \pm 11 \mathrm{Ma}(\mathrm{MSWD}=3.2$ ) (Fig. 5d). We suggest that this age is the best approximation of the crystallization age of the sample. Two analyses on cores of these 

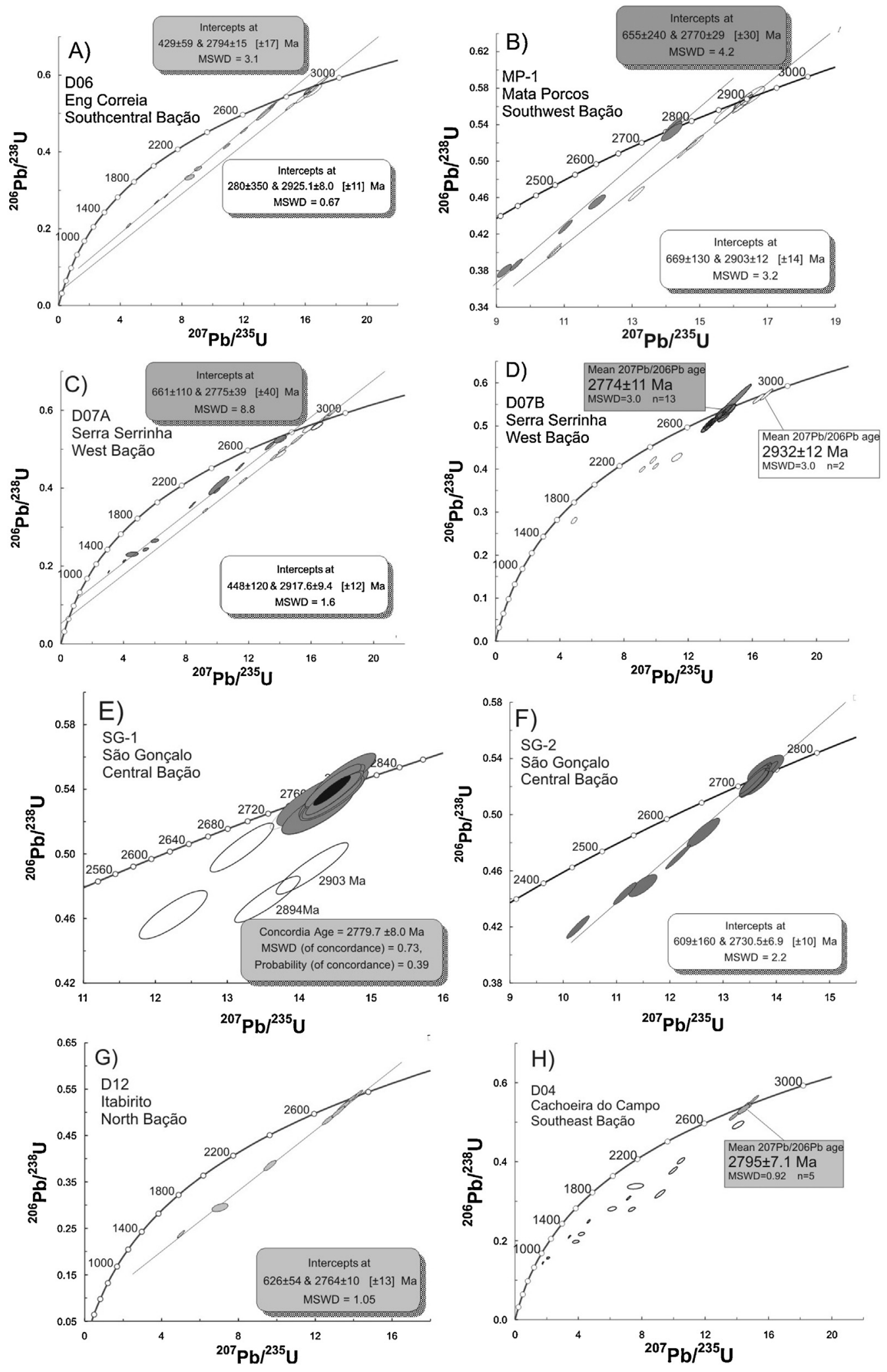

Fig. 5. U-Pb Concordia diagrams of SHRIMP and LA-ICP-MS analyses from TTG gneisses from the Bação Complex, Southern São Francisco Craton.

grains were concordant to sub-concordant and gave a ${ }^{207} \mathrm{~Pb} /{ }^{206} \mathrm{~Pb}$ mean age of $2931 \pm 12 \mathrm{Ma}(\mathrm{MSWD}=3.0)$. We interpret these cores as inherited, most likely from the host TTG gneiss.

Sample SG-1 (UTM: 625589/7755071) comes from an amphibolite intrusion near São Gonçalo town (Fig. 4a and e). The host TTG rock is compositionally similar to the banded gneisses sampled previously. Both TTG gneiss and amphibolite are strongly foliated and are crosscut by numerous phases of potassic granitoid sheets (Fig. 4e). Sample SG-1 contained a number of translucent grains with well-defined oscillatory zoning in $\mathrm{CL}$ images (Fig. 3). The grains were less complex than the ones described above: except for a couple of grains that contained zoned cores with resorbed 
terminations. Two analyses on the cores were fairly discordant with apparent ages of $2894 \pm 21 \mathrm{Ma}$ and $2903 \pm 22 \mathrm{Ma}$ (Fig. 5e). Thirteen analyses on the other zoned grains gave a well-defined concordia age of $2778 \pm 8 \mathrm{Ma}(\mathrm{MSWD}=0.73$ ) (Fig. 5e). Sample SG2 comes from the cross cutting potassic granitoid sheet. This rock consists dominantly of plagioclase, quartz, K-feldspar and biotite, similar in many aspects to the vertical sheets described in Romano et al. (2013). The zircons were translucent to partly translucent and showed well-defined oscillatory zoning in CL images. Twenty points in these grains define a Pb-loss regression which intercept the Concordia at $609 \pm 130 \mathrm{Ma}$ and $2730 \pm 7 \mathrm{Ma}(\mathrm{MSWD}=2.2$ ) (Fig. 5f). The older age (upper intercept) is identical to several samples of potassic granitoids (see Romano et al., 2013 and references therein) and is here interpreted as the crystallization age of the sample.

Sample D12 (UTM: 0625664/7762166) represents a large body of weakly foliated granodiorite that is exposed a few kms away from the northern border of the dome, to the northwest of the Itabirito town (Fig. 4a). This sample yielded milky white, heavily fractured zircons, ranging in size from 80 to $300 \mu \mathrm{m}$. CL-images show well-zoned internal structures, rimmed by structureless dark rims (Fig. 3). SHRIMP analyses show that the rims are richer in $U$ relative to the zoned cores ( $\mathrm{Th} / \mathrm{U}<0.2$ ), and yielded the most discordant results. No reliable age data was obtained from these rims. Nine analyses on the zoned cores yielded concordant to subconcordant results that defined a $\mathrm{Pb}$-Discordia with an upper intercept age of $2764 \pm 10 \mathrm{Ma}$ (MSWD =0.9) (Fig. 5g). This age is slightly younger than the previous crystallization ages, but it overlaps (within error) with the $2774 \pm 11 \mathrm{Ma}$ age obtained for Sample D07A (Fig. 5c), from the Serrinha Quarry, southwest of Itabirito. It is interpreted as the crystallization age of the sample.

Sample D04 (UTM: 0637825/7750333) was collected from a quarry outcrop in the southeastern sector of the Bação dome, a few kilometres from the town Cachoeira do Campo (Fig. 4a). It represents a banded trondhjemitic gneiss, characterized by vertical, $\mathrm{mm}$ - to $\mathrm{cm}$-wide leucocratic and mesocratic bands. The mesocratic bands are rich in plagioclase and biotite, whereas the leucocratic bands contain predominantly plagioclase, quartz and minor microcline. The gneiss is locally cross-cut by subvertical sheets of potassic granitoids that are intruded subparallel to the gneiss vertical banding (Fig. 4f). This sample yielded a number of milky white to dark brown zircons that are of poor quality for $\mathrm{U}-\mathrm{Pb}$ dating. Totally altered, milky white grains were discarded. The remaining $10-15 \%$ of the separate contained subhedral to anhedral, partly translucent zircons, with broad zones of intense alteration and radiation damage. The least altered zircon grains or areas within grains were targeted for analysis. Twenty SHRIMP analyses gave a poorly constrained Pb-loss Discordia regression line due to severe $\mathrm{Pb}$-loss disturbance (highly discordant points). No intercept age was attempted. Five of these points are, however, concordant or near-concordant $\left(>96 \%\right.$ ) to give confidence in a ${ }^{207} \mathrm{~Pb} /{ }^{206} \mathrm{~Pb}$ age calculated from these selected data. $\mathrm{A}^{207} \mathrm{~Pb} /{ }^{206} \mathrm{~Pb}$ weighted mean age of $2795 \pm 7 \mathrm{Ma}(\mathrm{MSWD}=0.92$ ) was obtained for these datapoints (Fig. 5h). This $2795 \pm 7 \mathrm{Ma}$ age is interpreted as the crystallization age of the sample.

\subsubsection{Belo Horizonte Complex}

The Belo Horizonte Complex corresponds to the largest segment of TTG crust in the study area (Fig. 6a). It was initially investigated by Machado et al. (1992) and Noce (1995). The majority of the exposures consist of strongly banded gneisses (Fig. 6b and c) with dominant amphibolite-facies foliation. Two main trondhjemitic phases that record a strong solid state foliation occur along the southeastern margin of the domal structure. The dominant phase is a fine-grained trondhjemite consisting of plagioclase, biotite, quartz and minor microcline (Fig. 6d). The penetrative fabric is mainly defined by the preferred orientation of biotite and stretched plagiocase. This fine-grained phase alternates with a porphyritic trondhjemite that contains a similar mineralogy but with $\mathrm{cm}$-size, strongly stretched plagioclase porphyroclasts. The only sample previously dated from this complex comes from the central part of the structure (Noce, 1995; Noce et al., 1998). These authors obtained a TIMS zircon U-Pb upper intercept age of $2860 \pm 14$ Ma from a migmatite. However, this age was obtained from fairly discordant grains, due to the strong metamict nature of the zircons.

We have attempted to date the banded gneiss (Sample D14) in the central part of the Belo Horizonte dome and the trondhjemite phases in the southeast: the fine-grained (sample CO-1) and coarse-grained (Sample CO-2) phases. However, sample CO2 yielded only milky white grains that gave very poor $\mathrm{U}-\mathrm{Pb}$ age data. No data reduction was attempted. Likewise, sample CO-2 (UTM: 662232/7758014) contains a large number of short prismatic zircons with structureless cores (Fig. 3), surrounded by zoned rims. LA-ICP-MS analyses on the cores gave unreliable U-Pb data, with high $U$ concentrations - these analyses were discarded. Data obtained from the magmatic rims were substantially more consistent, with 12 points plotting around a Pb-loss Discordia that intercepts the concordia at ca. $700 \mathrm{Ma}$ and $2900 \mathrm{Ma}$. Two points were identified as an outlier from this group, with a significantly lower ${ }^{207} \mathrm{~Pb} /{ }^{206} \mathrm{~Pb}$ ratios. As these points were sited side-by-side within the same zircon, this discrepancy is attributed to local heterogeneity resulting from variable early radiogenic Pb-loss. Ten other points define a Pb-loss cord that intercepts the Concordia at $747 \pm 150 \mathrm{Ma}$ and $2919 \pm 12 \mathrm{Ma}(\mathrm{MSWD}=2.3$ ) (Fig. 7a). We interpret the $2919 \pm 12$ Ma age as the crystallization age of the sample.

Sample D14 (UTM: 0592565/7792672) represents a banded gneiss from the western parts of the Belo Horizonte dome, well exposed on a road cut a few $\mathrm{km}$ from Betim (Fig. 6c). This gneiss is intruded by several vertical sheets of potassic granitoids. The sample contains milky white to dark brown zircons, which vary from prismatic to slightly stubby, all with round terminations. The grains are predominately dark in CL images due to high $\mathrm{U}$ content (Fig. 3). Some bright complex cores are observed but the relationship with the overgrowth is difficult to constrain. SHRIMP spot analyses in the cores seem to indicate one single population that crystallized at around $2800 \mathrm{Ma}$. The data points are dispersed along a line which does not pass through the origin but has a lower intersection with the Concordia curve at approximately 500 Ma. Eight of the most concordant data points have ${ }^{207} \mathrm{~Pb} /{ }^{206} \mathrm{~Pb}$ ages, which are identical within error, and give ${ }^{207} \mathrm{~Pb} /{ }^{206} \mathrm{~Pb}$ weighted mean age of $2783 \pm 23 \mathrm{Ma}(\mathrm{MSWD}=2.9$ ) (Fig. 7b). This age is identical to three other $\mathrm{Rb} / \mathrm{Sr}$ ages of $2803 \pm 80 \mathrm{Ma}, 2790 \pm 90 \mathrm{Ma}$ and $2798 \pm 73 \mathrm{Ma}$ obtained for TTG gneiss in the same area (western part of the dome) (Teixeira et al., 1996). We interpret the $2783 \pm 23$ Ma age as the best estimate of the crystallization age for this sample. Two concordant/subconcordant points that were too young relative to the main $2783 \mathrm{Ma}$ population gave a ${ }^{207} \mathrm{~Pb} /{ }^{206} \mathrm{~Pb}$ weighted mean age of $2716 \pm 9 \mathrm{Ma}$, which is rather close to the ages obtained for the potassic granitoids (Romano et al., 2013). However, these two points came from one grain, which is compositionally distinct from the rest of the population. We believe that this is a case of sample contamination, given the banded nature of this rock, or a result of authigenic growth during emplacement of the potassic granitoids.

\subsubsection{Bonfim Complex}

The Bonfim Complex comprises the second largest segment of TTG crust in the Southern São Francisco Craton (Fig. 6a). The Bonfim dome exposes TTG gneisses in the core and a thick sheet of potassic granitoids on its periphery (Romano et al., 2013). The basement gneisses record a N-S trending, subvertical foliation that is marked by complex, polyphase history of folding. This gneissosity is crosscut by the 2780 Ma Samambaia tonalite (Machado and Carneiro, 


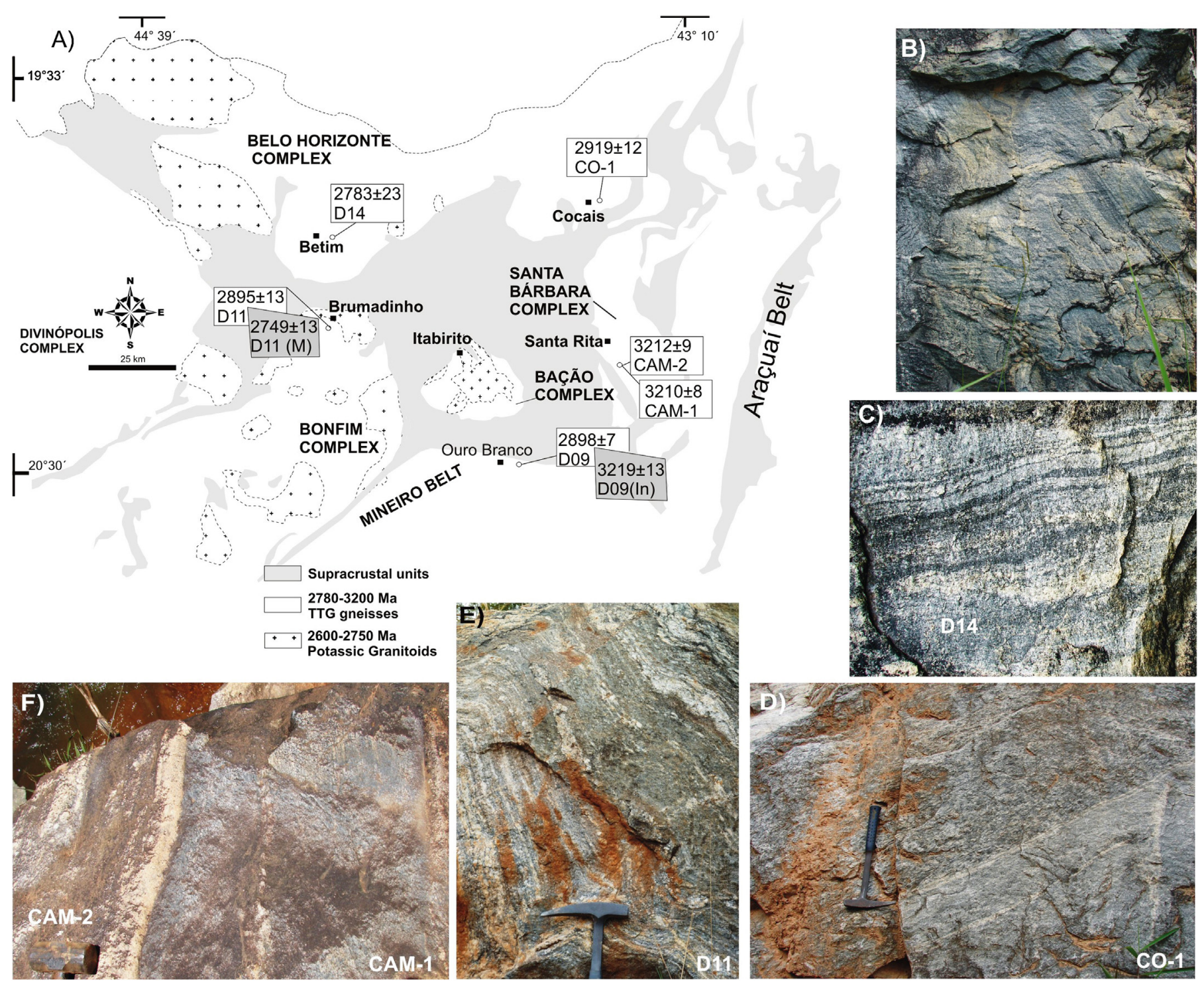

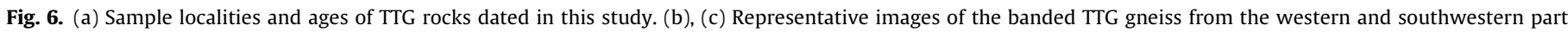

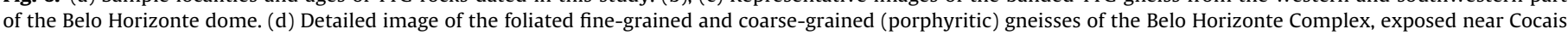

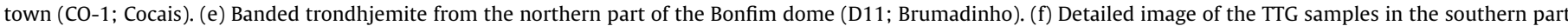

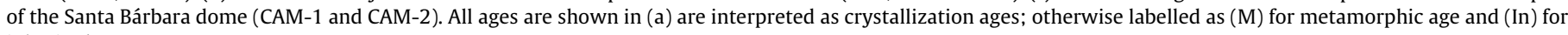
inherited.

1992) and numerous phases of vertical potassic granitoid bodies. Zircon U-Pb age data from Machado and Carneiro (1992), Noce (1995) and Romano et al. (2013) indicate that almost all potassic granitoid phases range in age from 2700 to $2730 \mathrm{Ma}$, except for two small occurrences that seemingly record an age of 2614-2615 Ma.

Sample D11 (UTM: 0588164/7770431) represents a banded tonalitic gneiss exposed along a road cut in the northern sector of the complex, a few kilometres south of a large batholith of potassic granitoid (Fig. 6a). The gneiss records strong subvertical foliation that is intruded by multiple foliation-parallel leucocratic sheets. As shown in Fig. 6e, the gneiss foliation is represented by aligned biotite and amphibole crystals as well as elongated quartz + plagioclase pods of potassic granitoid melt. Zircons from the sample are prismatic with round terminations. They range in colour from milky white to light brown. Partly transparent zircons ( $\sim 10 \%$ of the fraction) record well-defined oscillatory zones, typical of magmatic zircons, which in turn are truncated by thin bright overgrowths. Fifteen SHRIMP U-Pb analyses on the magmatic zones of these zircons gave a Pb-loss Discordia line that intercepts the Concordia at $537 \pm 55 \mathrm{Ma}$ and $2895 \pm 13 \mathrm{Ma}$ $(\mathrm{MSWD}=1.9)$ (Fig. 7c). We interpret this age as the crystallization age of the sample. Analyses on the rims gave significantly younger ages and slightly lower $\mathrm{Th} / \mathrm{U}$ ratios. These analyses define a Discordia line that intercepts the Concordia at $479 \pm 25 \mathrm{Ma}$ and $2749 \pm 10 \mathrm{Ma}(\mathrm{MSWD}=1.0)$. This age is within error of the age of the potassic granitoids, and reflects the crystallization of the foliationparallel leucogranite sheets (Fig. 6e).

\subsubsection{Santa Bárbara Complex}

The Santa Bárbara dome in the eastern part of the QF (Fig. 6a) is the only segment of TTG crust that has not been mapped in detail. One of only a few outcrop localities in the dome exposes two phases of strongly foliated, locally banded TTG gneiss (Fig. 6f). One phase is coarse-grained, light grey that intrudes a rather fine-grained, biotite-rich trondhjemite phase (Fig. 6a). The two phases were sampled (Samples CAM-1 and CAM-2; UTM: 625589/7755071). Both contained very similar looking grains with well-preserved magmatic zoning (Fig. 3). They are euhedral, rather ellipsoidal in shape, 

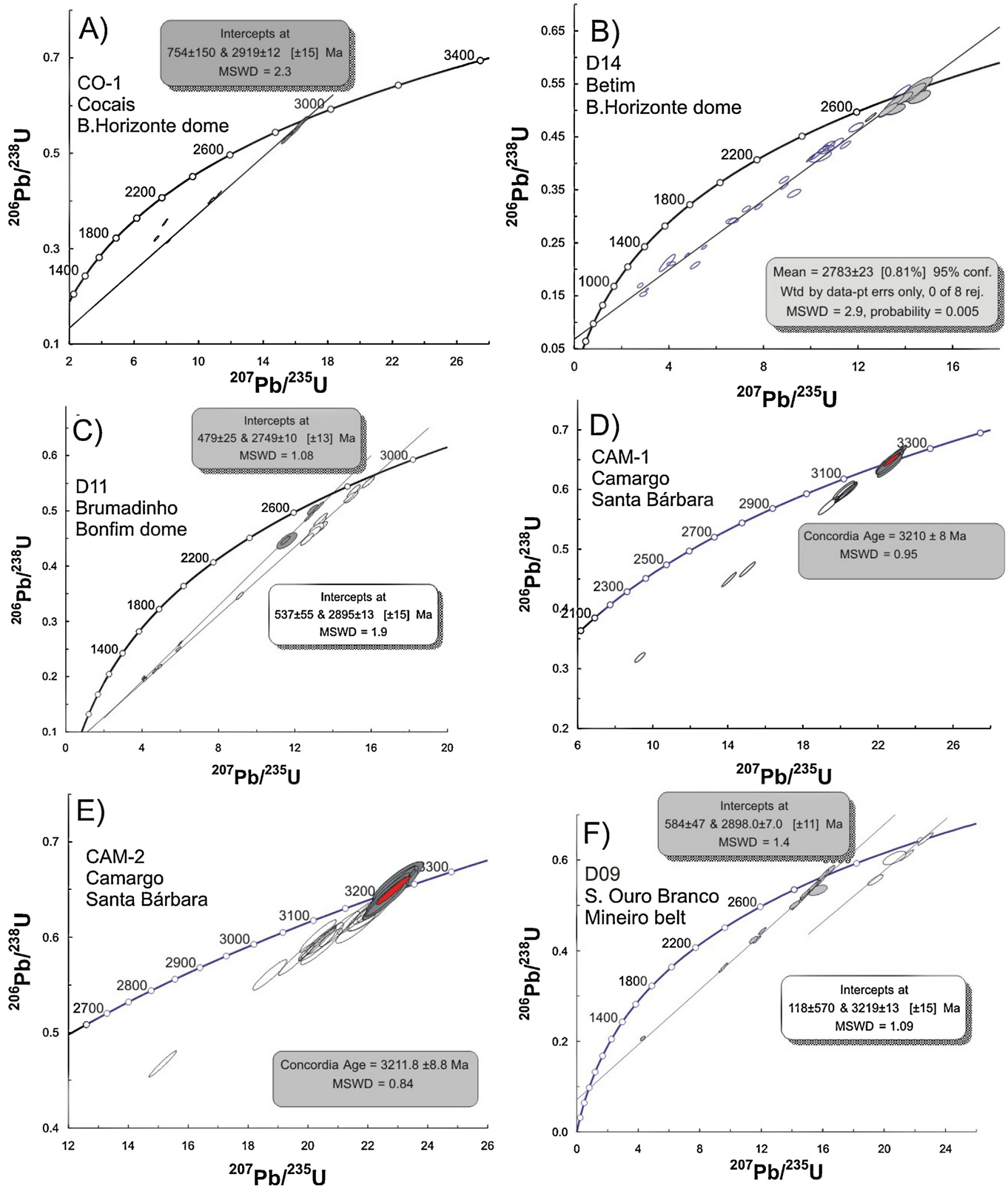

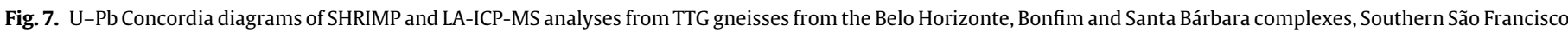
Craton, and one sample from the reworked basement from the Mineiro Belt.

multi-faceted and strongly zoned. No clear core-rim structure was observed. Thirty-one LA-ICP-MS analyses on the centre and border of zircons from Sample CAM-1 seem to represent one single population. These points define a Pb-loss Discordia line that intercepts upper Concordia at circa $3200 \mathrm{Ma}$. Twenty-three of these grains gave a concordia age of $3210 \pm 8 \mathrm{Ma}(\mathrm{MSWD}=0.95)$ (Fig. 7d). Sample CAM-2 yielded similar results. Thirty-five grains were analyzed via LA-ICP-MS. The analyses define a Discordia regression line that 
intercepts the upper Concordia at ca. 3210 Ma. Nineteen concordant grains gave a concordia age of $3212 \pm 9 \mathrm{Ma}(\mathrm{MSWD}=0.84)$ (Fig. 7e). These ages indicate that these phases were co-magmatic and that they crystallized between 3210 and $3212 \mathrm{Ma}$.

\subsubsection{Reworked basement of the Mineiro Belt}

The Mineiro Belt evolved as a marginal belt to the southern end of the Archaean nucleus of the São Francisco Craton. To the south of the Quadrilátero Ferrífero, the belt includes a large area of reworked Archaean TTG and potassic granitoid rocks that is largely intruded by several 2300-2100 Ma Palaeoproterozoic granitoid plutons and mafic bodies, also with $<2100$ Ma supracrustal sequences present (Fig. 1) (Teixeira and Figueiredo, 1991; Teixeira et al., 2000; Noce et al., 2007; Seixas et al., 2012).

One sample of a coarse-grained massive trondhjemite (Sample D09; Fig. 6a; UTM: 0639642/7730692), located a few hundrends of metres from the contact with the greenstone belt/supracrustal rocks of the QF (Serra de Ouro Branco; Fig. 6a), was chosen as representative of the reworked basement rocks of the Mineiro Belt. This sample yielded translucent to partly translucent grains, many of which were coated with a few $\mu \mathrm{m}$-width rims of alteration. CL-images show structureless, bright cores surrounded by CLbright overgrowths. Four spot analyses on the cores gave apparent ${ }^{207} \mathrm{~Pb} /{ }^{206} \mathrm{~Pb}$ ages ranging from 3211 to $2846 \mathrm{Ma}$. They define $\mathrm{a} \mathrm{Pb}-$ loss Discordia that intercepts the upper Concordia at $3219 \pm 13 \mathrm{Ma}$ (MSWD =1.09) (Fig. 7f). Spot analyses on the overgrowths gave significantly younger ages, and define a regression line that passes through the Concordia at $2898 \pm 7 \mathrm{Ma}(\mathrm{MSWD}=1.4)$. We interpret this age the crystallization age.

\section{Summary}

Previous studies have made a case that the TTG crust in and around the Quadrilátero Ferrífero experienced a complex polyphase magmatic evolution prior to the emplacement of $\mathrm{km}$ scale batholiths of potassic granitoids (see also, Machado and Carneiro, 1992; Machado et al., 1996; Teixeira et al., 1996; Carneiro et al., 1997; Noce et al., 1998, 2005). In contrast to the rather undeformed nature of the potassic granitoids, the TTG rocks record field evidence of multiple stages of magmatic intrusion (Carneiro et al., 1997; Noce et al., 1998) and a complex pattern of amphibolitefacies foliation. After careful examination of the zircon morphology and internal structures we were able to obtain by SHRIMP and LA-ICP-MS methods a concise U-Pb age dataset for 14 samples. When combined with previously published zircon $\mathrm{U}-\mathrm{Pb}$ age data, the results indicate a protracted magmatic evolution for the TTG crust (Table 1), with at least three main periods of TTG magmatism and one metamorphic event (Table 1). The magmatic events are hereafter referred to as the Santa Bárbara (3220-3200 Ma), Rio das Velhas I (RV I, 2930-2900 Ma) and Rio das Velhas II (RV II, 2800-2770 Ma) events (Table 1).

The Santa Bárbara event is marked by the emplacement of the $3212 \pm 9$ and $3210 \pm 8$ Ma TTG rocks in the SB complex and the 3219 Ma rock in the Mineiro Belt (Fig. 6). Although these rocks are the only direct evidence of Palaeoarchaean crustal evolution in the area, Sm-Nd model ages from the TTG rocks (Teixeira et al., 1996) and detrital zircons from the main greenstone belt (see Machado et al., 1992, 1996) may indicate the existence of other fragments of Palaeoarchaean TTG crust in the province. For instance, a compilation of the detrital zircon dataset from Machado et al. (1996) and Hartmann et al. (2006) shows a large number of Palaeoarchaean detrital grains, defining a spectrum from 3600 to $3000 \mathrm{Ma}$ (Fig. 8). Zircon separates from the Minas and Rio das Velhas clastic sediments yielded more than 30 grains ranging in age from 3250 to
$3200 \mathrm{Ma}$. This compilation suggests that older sources $>3300 \mathrm{Ma}$ may have existed prior to the deposition of the Minas Basin.

The Rio das Velhas I (RV I) event is represented by the 2930-2900 Ma TTG gneisses exposed in Bação, Belo Horizonte, and Bonfim domes as well as in the Mineiro Belt (Table 1). The widespread distribution of the ca. 2900 Ma rocks (Figs. 4 and 6), together with the inherited ages in TTG rocks that crystallized at ca. $2700 \mathrm{Ma}$ (RV II event: Table 1), indicate that much of the Southern São Francisco crust was already formed by 2900 Ma. Likewise, the detrital zircon dataset is particularly marked by a large number of ca. 2900 Ma grains, confirming the widespread preservation of the RV II TTG crust at the time of accumulation of the Rio das Velhas and Minas clastic sediments.

The Rio das Velhas II event took place between 2800 Ma and 2760 Ma. Six samples of TTG gneisses from the Caeté, Bação, Bonfim and Belo Horizonte complexes (Figs. 4 and 6), and one amphibolite sample from the Bação dome record crystallization ages that fall within this range (Table 1 ). Significantly, many of the rocks of the RV I record metamorphic ages that overlap (within error) with the magmatic ages of the RV II. We suggest that the entire crust around the QF was affected by magmatism and amphibolite-facies metamorphism at 2770-2800 Ma. The widespread occurrence of RVII ages in the QF is consistent with a magmatic event of similar magnitude to the RV I event.

\section{Implications for Archaean crustal development}

The generation of Archaean TTG rocks is a matter of a long standing debate. Geochemical evidence support the view that Archaean TTG assemblages form in arc settings, being thus ancient equivalents of modern subduction-related magmatic assemblages (e.g., Martin, 1993; Smithies et al., 2003, 2005; Rapp et al., 2003; Moyen et al., 2007; Foley et al., 2002). Considering the differences in the geochemical signatures of Archaean TTG suites and post-Archaean arc-related granitoids, several authors postulate that TTG magmas were generated through the melting of subducting oceanic slabs (e.g., Martin, 1999; Rapp et al., 2003). Alternatively, Archaean TTG suites are also viewed as a product of delamination of the base of oceanic plateaus (Bédard, 2006), i.e., not related to consumption of the oceanic lithosphere. Likewise, different models have been proposed for the generation of Archaean greenstone belt successions and their juxtaposition with the TTG crust. For instance, in the models that predict TTG generation through subduction-related magmatism, the greenstone belts are invariably interpreted as intra-oceanic thrust belts (oceanic terranes), sandwiched between the TTG-dominated sialic blocks (e.g., De Ronde and De Wit, 1994; De Wit, 1998; Percival et al., 2001; Windley and Garde, 2009). Although the modes of tectonic accretion remain unclear, evidence exists that blocks with different geological histories have amalgamated to form a number of Archaean granite-greenstone terrains (Nutman et al., 1989, 2002; Kusky and Polat, 1999; Percival et al., 1994, 2001; Smithies et al., 2003, 2005; Windley and Garde, 2009; Stott and Mueller, 2009; Lana et al., 2010a,b, 2011).

Terrains like the Barberton Terrain in South Africa (Anhaeusser, 1969, 1984; Armstrong et al., 1990) seem to include relatively small continental blocks that were amalgamated at some point in the Archaean (Armstrong et al., 1990; De Ronde and De Wit, 1994; Lowe, 1994; Kroner et al., 1996; De Wit, 1998; Kisters et al., 2010). Sedimentological features, structure, and age data variations across the Barberton Greenstone Belt, indicated to previous workers the presence of least two distinct terranes separated by a major tectonic discontinuity (Armstrong et al., 1990; De Wit et al., 1992; De Ronde and De Wit, 1994; De Ronde and Kamo, 2000; Lowe, 1994). Significantly, in the Barberton setting the isotopic signatures of syntectonic TTG intrusives are invariably in favour of emplacement 
Table 1

Summary of ages for TTG rocks in the Southern São Francisco Craton.

\begin{tabular}{|c|c|c|c|c|c|c|c|}
\hline Sample & Rock type & & Method & Inherited age & $\begin{array}{l}\text { Crystallization } \\
\text { age }\end{array}$ & $\begin{array}{l}\text { Metamorphic } \\
\text { age }\end{array}$ & References \\
\hline \multicolumn{8}{|c|}{ 3200-3220 Ma magmatic/volcanic event } \\
\hline CAM-1 & $\begin{array}{l}\text { Cachoeira } \\
\text { camargo } \\
\text { Trondhjemitic } \\
\text { gneiss }\end{array}$ & Santa Barbara & LA-ICP-MS & & $\begin{array}{l}3210 \pm 8 \mathrm{Ma} \\
(\mathrm{MSWD}=0.95)\end{array}$ & & This study \\
\hline CAM-2 & $\begin{array}{l}\text { Cachoeira } \\
\text { camargo } \\
\text { Trondhjemitic } \\
\text { gneiss }\end{array}$ & Santa Barbara & LA-ICP-MS & & $\begin{array}{l}3212+9 \mathrm{Ma} \\
(\mathrm{MSWD}=0.84)\end{array}$ & & This study \\
\hline \multicolumn{8}{|c|}{ 2900-2930 Ma magmatic/volcanic event } \\
\hline D06 & $\begin{array}{l}\text { Eng. Correia } \\
\text { Banded } \\
\text { trondhjemite }\end{array}$ & Bação & SHRIMP & & $\begin{array}{l}2925 \pm 8 \mathrm{Ma} \\
(\mathrm{MSWD}=0.67)\end{array}$ & $\begin{array}{l}2794 \pm 15 \mathrm{Ma} \\
(\mathrm{MSWD}=3.1)\end{array}$ & This study \\
\hline \multirow[t]{2}{*}{ MP-1 } & $\begin{array}{l}\text { Eng. Correia } \\
\text { Trondhjemite } \\
\text { band }\end{array}$ & Bação & LA-ICP-MS & & $\begin{array}{l}2902 \pm 12 \mathrm{Ma} \\
(\mathrm{MSWD}=3.2)\end{array}$ & $\begin{array}{l}2770 \pm 29 \mathrm{Ma} \\
(\mathrm{MSWD}=4.2)\end{array}$ & This study \\
\hline & $\begin{array}{l}\text { Alberto Flores } \\
\text { Gneiss } \\
\text { Banded } \\
\text { trondhjemite }\end{array}$ & Bonfim & TIMS & & $2920 \pm 5 \mathrm{Ma}$ & $2772 \pm 6 \mathrm{Ma}$ & $\begin{array}{l}\text { Machado and } \\
\text { Carneiro (1992) }\end{array}$ \\
\hline D07A & $\begin{array}{l}\text { Serrinha } \\
\text { Trondhjemite } \\
\text { band }\end{array}$ & Bação & SHRIMP & & $\begin{array}{l}2918 \pm 10 \mathrm{Ma} \\
(\mathrm{MSWD}=1.6)\end{array}$ & $\begin{array}{l}2775 \pm 39 \\
(M S W D=8.8)\end{array}$ & This study \\
\hline D11 & $\begin{array}{l}\text { Brumadinho } \\
\text { Banded } \\
\text { trondhjemite }\end{array}$ & Bonfim & SHRIMP & & $\begin{array}{l}2895 \pm 13 \mathrm{Ma} \\
(\mathrm{MSWD}=1.9)\end{array}$ & $\begin{array}{l}2749 \pm 10 \mathrm{Ma} \\
(\mathrm{MSWD}=1.0)\end{array}$ & This study \\
\hline D09 & $\begin{array}{l}\text { Serra de Ouro } \\
\text { Branco } \\
\text { Trondhjemtie }\end{array}$ & Mineiro Belt & SHRIMP & $\begin{array}{l}3219 \pm 13 \mathrm{Ma} \\
(\mathrm{MSWD}=1.09)\end{array}$ & $\begin{array}{l}2898 \pm 7 \mathrm{Ma} \\
(\mathrm{MSWD}=1.4)\end{array}$ & & This study \\
\hline $\mathrm{CO}-1$ & $\begin{array}{l}\text { Cocais } \\
\text { Foliated } \\
\text { trondhjemite }\end{array}$ & Belo Horizonte & LA-ICP-MS & $3258 \pm 14 \mathrm{Ma}$ & $\begin{array}{l}2919 \pm 12 \mathrm{Ma} \\
(\mathrm{MSWD}=2.3)\end{array}$ & & This study \\
\hline \multicolumn{8}{|c|}{ 2760-2800 Ma magmatic event } \\
\hline D07B & $\begin{array}{l}\text { Caete } \\
\text { Trondhjemite } \\
\text { gneiss }\end{array}$ & Caete & TIMS & & $2776 \pm 6 \mathrm{Ma}$ & & $\begin{array}{l}\text { Machado et al. } \\
\text { (1992) }\end{array}$ \\
\hline & $\begin{array}{l}\text { Serrinha } \\
\text { Leucocratic } \\
\text { band }\end{array}$ & Bação & SHRIMP & $\begin{array}{l}2931 \pm 12 \mathrm{Ma} \\
(\mathrm{MSWD}=3.0)\end{array}$ & $\begin{array}{l}2774 \pm 11 \mathrm{Ma} \\
(\mathrm{MSWD}=3.2)\end{array}$ & & This study \\
\hline SG-1 & $\begin{array}{l}\text { São Gonçalo } \\
\text { Amphibolite }\end{array}$ & Bação & LA-ICP-MS & $>2903 \pm 22$ & $\begin{array}{l}2800 \pm 8 \mathrm{Ma} \\
(\mathrm{MSWD}=0.73)\end{array}$ & & This study \\
\hline D12 & $\begin{array}{l}\text { Itabirito } \\
\text { Granodiorite }\end{array}$ & Bação & SHRIMP & & $\begin{array}{l}2764 \pm 10 \mathrm{Ma} \\
(\mathrm{MSWD}=0.9)\end{array}$ & & This study \\
\hline D04 & $\begin{array}{l}\text { Caixoeira do } \\
\text { Campo } \\
\text { Trondhjemite } \\
\text { gneiss }\end{array}$ & Bação & SHRIMP & & $\begin{array}{l}2795 \pm 7 \mathrm{Ma} \\
(\mathrm{MSWD}=0.92)\end{array}$ & & This study \\
\hline D14 & $\begin{array}{l}\text { Betin } \\
\text { Banded Gneiss } \\
\text { Samambaia } \\
\text { Tonalite }\end{array}$ & $\begin{array}{l}\text { Belo Horizonte } \\
\text { Bonfim }\end{array}$ & $\begin{array}{l}\text { SHRIMP } \\
\text { TIMS }\end{array}$ & & $\begin{array}{l}2783 \pm 23 \mathrm{Ma} \\
(\mathrm{MSWD}=2.9) \\
2778 \pm 3 \mathrm{Ma}\end{array}$ & & $\begin{array}{l}\text { This study } \\
\text { Machado and } \\
\text { Carneiro (1992) }\end{array}$ \\
\hline \multicolumn{8}{|c|}{ 2750-2800 Ma volcanic event in the Rio das Velhas Greenstone Belt } \\
\hline \multirow[t]{2}{*}{ FR-38 } & $\begin{array}{l}\text { Rio das Velhas } \\
\text { Group } \\
\text { Volcanic rocks }\end{array}$ & Supracrustals & TIMS & $2883 \pm 6 \mathrm{Ma}$ & $2776 \pm 26 \mathrm{Ma}$ & & $\begin{array}{l}\text { Machado et al. } \\
\text { (1992) }\end{array}$ \\
\hline & $\begin{array}{l}\text { Rio das Velhas } \\
\text { Group } \\
\text { Volcanic rocks }\end{array}$ & Supracrustals & SHRIMP & $>3000 \mathrm{Ma}$ & $2792 \pm 11 \mathrm{Ma}$ & & $\begin{array}{l}\text { Noce et al. } \\
\text { (2005) }\end{array}$ \\
\hline MZ-53 & $\begin{array}{l}\text { Rio das Velhas } \\
\text { Group } \\
\text { Volcanic rocks }\end{array}$ & Supracrustals & TIMS & $2928 \pm 14 \mathrm{Ma}$ & $2751 \pm 11 \mathrm{Ma}$ & & $\begin{array}{l}\text { Noce et al. } \\
\text { (2005) }\end{array}$ \\
\hline SS-144 & $\begin{array}{l}\text { Rio das Velhas } \\
\text { Group } \\
\text { Volcanic rocks }\end{array}$ & Supracrustals & TIMS & $3035 \pm 5 \mathrm{Ma}$ & $2777 \pm 7 \mathrm{Ma}$ & & $\begin{array}{l}\text { Noce et al. } \\
\text { (2005) }\end{array}$ \\
\hline
\end{tabular}




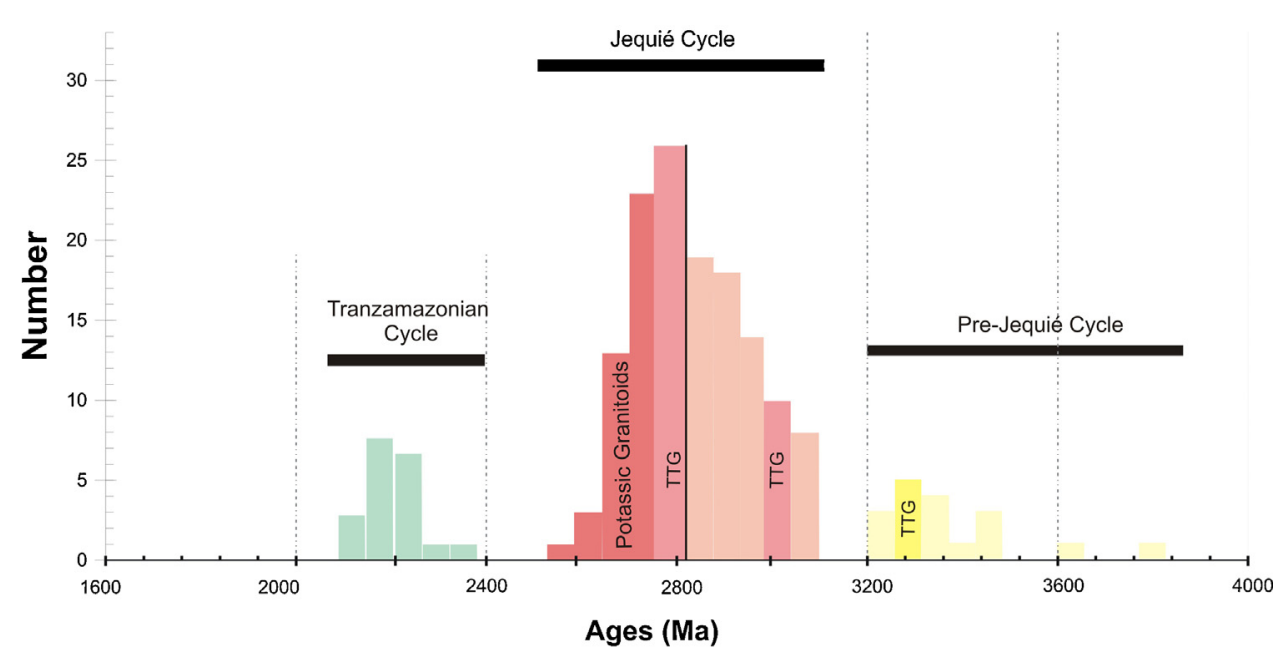

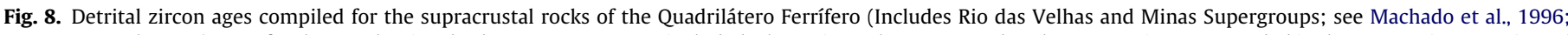

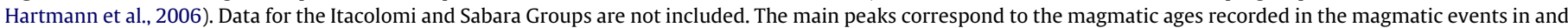
around the QF province. The magmatism is subdivided into Santa Bárbara, Rio das Velhas and Potassic Granitoid event. See discussion for details.

in continental arc settings prior or during terrain amalgamation (Schoene et al., 2008, 2009).

The Quadrilátero Ferrífero province constitutes an area equivalent or slightly smaller than that occupied by the Barberton Terrain. Features recorded in the Rio das Velhas greenstone belt are consistent with intra-oceanic mafic-ultramafic magmatism, responsible for development of pillowed basaltic lavas, and their intercalation with carbonate and banded iron formation sediments (e.g., Ladeira, 1980; Zucchetti et al., 2000a,b; Baltazar and Zucchetti, 2007). However, in contrast to other greenstone belt provinces, blocks with distinct tectonomagmatic histories cannot be identified judging the fact that the granitoid-gneiss complexes (e.g., Bação,
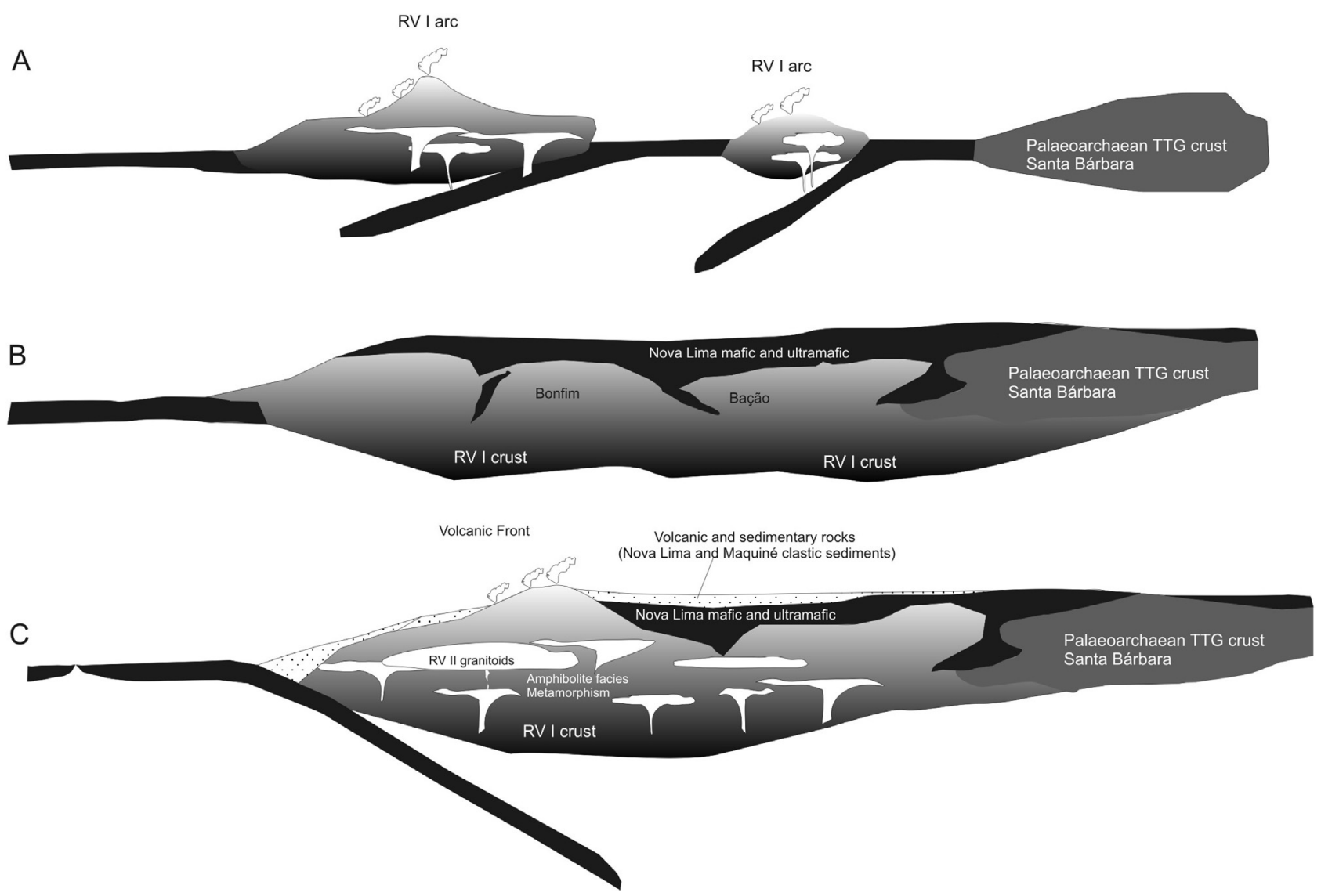

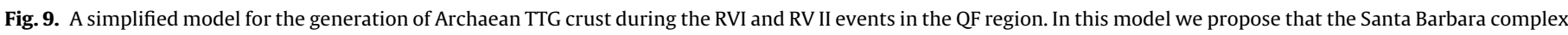

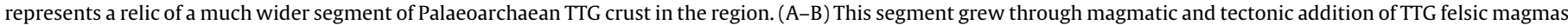

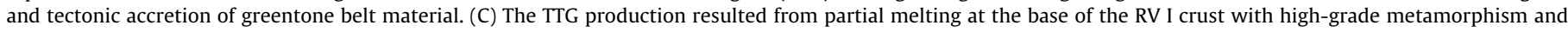

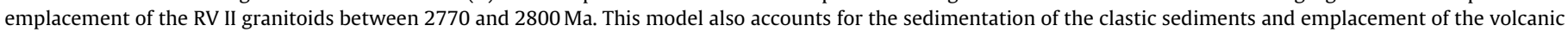
rocks in the Rio das Velhas Greenstone Belt. 
Belo Horizonte, Bonfim) record identical magmatic events: they were affected by both RVI and RV II TTG events.

Our zircon $\mathrm{U}-\mathrm{Pb}$ data shows that the magmatic evolution of the TTG crust began as early as $3200 \mathrm{Ma}$ with the emplacement of the 3210 Ma Santa Bárbara TTG rocks (samples CAM-1 and CAM-2) and a reworked granitoid in the Mineiro Belt (sample D9). We observed that 3250-3200 Ma zircons occur as inherited components in a limited number of samples, but they represent a significant subset in the detrital spectra of the greenstone belt clastic succession (Maquiné Group; Machado et al., 1996 - Fig. 8) and the Palaeoproterozoic Minas Supergroup (Machado et al., 1996; Hartmann et al., 2006). A possible explanation for this fact is that the QF province began with a large segment of $>3200 \mathrm{Ma}$ Palaeoarchaean TTG crust and that this segment was either partly consumed (reworked) or partly eroded during tectonic denudation and intermittent magmatic activities at ca. 2930-2900 Ma (RVI event), 2800-2770 Ma (RV II event) and 2750-2700 (potassic granitoid event). Given that these Palaeoarchaean zircons do not show any evidence metamorphic overgrowth (Table 1 ), we suggest that Santa Barbara complex represent a well preserved core of this Palaeoarchaean crust, developed through additions of juvenile TTG magmas into mafic-ultramafic greenstone belt rocks. This core served as the main building block that grew through tectonic accretions of younger, 2900 Ma TTG terrain (Figs. 9a and b).

Evidence for the 2930-2900 Ma RV I TTG magmatism is present in almost all granitoid-gneiss complexes, surrounded by the Rio das Velhas Greenstone Belt - namely the Bação, Bonfim and Belo Horizonte complexes, as well as in the reworked basement of the Palaeoproterozoic Mineiro Belt (Figs. 4 and 6). Such a spatial distribution of RV I rocks testifies to the regional extent of the Neoarchaean TTG production, encompassing ca. $70 \%$ of the $\mathrm{QF}$ area (Figs. 2, 4 and 6). The RVI event is possibly linked to the first emergence of a regional continental lithosphere in the Southern São Francisco Craton (Fig. 9b). This process may have involved not only additions of TTG magmas in the Palaeoachaean crust, but also tectonic accretion of mafic and ultramafic rocks that are represented by the basal units of the Rio das Velhas Supergroup and by greenstone belt remnants around the margin of the Southern São Francisco Craton.

The 2800-2770 RVII magmatic event overlaps in age with the extrusion of felsic volcanic units and fluvial/turbiditic sedimentation on top of mafic-ultramafic lavas of the Rio das Velhas greenstone belt (Table 1). Primary sedimentary/volcanic structures within the most preserved part of the belt link the RV II felsic volcanic units with alluvial-fluvial lithofacies which, in turn, change abruptly to turbiditic deposits of submarine fans (Upper Nova Lima and Maquiné Groups). Both felsic volcanism and the turbiditic sedimentation are interpreted to mark the initial stages of a subduction episode ca. 2800 Ma (Baltazar and Zucchetti, 2007). The clastic sediments and volcanoclastics contain a number of detrital zircons ranging in age from to 3200 to $2780 \mathrm{Ma}$ (Machado et al., 1996; Hartmann et al., 2006) suggesting that all previously described components of the QF TTG crust served as sources during their deposition. Significantly, published negative $\varepsilon_{\mathrm{Nd}}(t)$ values calculated for the $2770 \mathrm{Ma}$ amphibolites and tonalities, and late $2700 \mathrm{Ma}$ potassic granites indicate that older $(>2900 \mathrm{Ma})$ sialic crust participated in their petrogenesis (Teixeira et al., 1996). According to Teixeira et al. (1996), intrusive 2770 Ma tonalites and late potassic granites are marked by different negative $\varepsilon_{\mathrm{Nd}}(t)$ values, suggesting that different proportions of sialic material participated in their origin. Thus, it is likely that the RVII TTG rocks and associated volcanic rocks were emplaced in volcanic-arc systems developed around the margins of the 3220-2900 Ma continental block (Fig. 8b). This explains the fact that a number of $2900 \mathrm{Ma}$ zircons (RV I zircons) record metamorphic overgrowths between at ca. 2750-2800 Ma (Table 1).

\section{Conclusions}

Our zircon U-Pb data provided, for the first time, a more detailed evolution of the Palaeo- to Neoarchaean TTG crust in the Southern São Francisco Craton. The main periods of TTG production - the Santa Barbara, Rio das Velhas I and Rio das Velhas II events - represent a significant part of the protracted tectonomagmatic history of the Craton spanning from 3220 to $2770 \mathrm{Ma}$. Based on the spatial and age distribution of the TTG rocks we suggest that the Santa Barbara TTG rocks represent the only relic of the Palaeoarchaean crust of the Southern São Francisco Craton. This crust grew into a large segment of TTG crust during two main events of subduction related magmatism in the Neoarchaean. These stages of TTG magmatism led to development of a composite, polydeformed TTG crust riddled with mafic-ultramafic greenstone belt terrains. The two main magmatic events (Rio das Velhas I and II events) span over a period of 30-40 Ma each, and are marked by voluminous emplacement of TTG magmas. The additions of juvenile and reworked TTG crust preceded the stabilization of the Sourthern São Francisco Craton by at least $70 \mathrm{Ma}$. The timing and duration of the latest TTG event (RV II) coincided with the felsic volcanism and deposition of turbiditic wackes of the main greenstone belt sequence. This same event was shortly followed by emplacement voluminous potassic granitoid magmas that led to construction of massive sheets of granitoids ranging in age from 2750 to $2700 \mathrm{Ma}$.

\section{Acknowledgements}

This material is based on work supported by FAPEMIG/CNPq under grant numbers FAPEMIG/VALE-RDP-00067-10 and FAPEMIG-APQ 03943-10 awarded to Cristiano Lana and CNPq grant 480317/2010-0 to Fernando Alkmim. SHRIMP analyses were sponsored by CNPq grant 480317/2010-0. Editor G.C. Zhao and two anonymous reviewers are greatly acknowledged for constructive reviews on this manuscript.

\section{Appendix A. U-Pb methodology}

Zircons were extracted at the Departamento de Geologia (DEGEO), Universidade Federal de Ouro Preto. The technique makes use of conventional jaw crusher, milling, manual panning and heavy liquids separation. The zircons were hand-picked under a binocular microscope and mounted on $25 \mathrm{~mm}$ epoxy mounts. The mounts were polished and imaged under SEMcathodoluminescence to accentuate internal growth zoning. For SHRIMP analysis, the mount was coated by an ultrathin pure gold coating to provide surface conductivity.

\section{A.1. SHRIMP}

The $\mathrm{U}$, Th and $\mathrm{Pb}$ isotopic data from samples MD4, MD6, MD7A, MD7B, MD9, and MD12 were collected on the Sensitive High Mass Resolution Ion Microprobe (SHRIMP RG) at the Research School of Earth Sciences at the Australian National University, Australia. The current of the O2-beam during the analytical sessions was set at least $2 \mathrm{nA}$, resulting in a sensitivity of $15-30 \mathrm{cps} / \mathrm{nA} / \mathrm{ppm}$ $\mathrm{Pb}$. Analyses on unknowns were interspersed with analyses of Temora standard, for which an age of $416.75 \pm 0.24$ Ma was adopted (Black et al., 2003). Calibration for U content was done through the SL13 zircon standard, which has a reported U content of $238 \mathrm{ppm}$ (Williams and Claesson, 1987). Measured compositions were corrected for common lead using measured non-radiogenic $204 \mathrm{~Pb}$. Analyses that displayed high counts on $204 \mathrm{~Pb}$, were abandoned, so that applied corrections are minimal and insensitive to the chosen isotopic composition of common $\mathrm{Pb}$. In all analyses, the component 
of common $\mathrm{Pb}$ related to surface contamination was minimized through the meticulous cleaning procedure prior to loading and rastering the primary beam over the analyzed area for up to 2 min prior to analysis. Common $\mathrm{Pb}$ counts were therefore observed to be constant and low. An average crustal $\mathrm{Pb}$ isotopic composition following the model of Stacey and Kramers (1975) was used in the common $\mathrm{Pb}$ correction, appropriate to the age of the zircon. Data processing was done using the excel add-ins Squid and Isoplot (Ludwig, 2001a,b, 2003). All decay constants are those recommended by Steiger and Jäger (1977), but for calculation of the ages, the uncertainties on these constants are not applied.

\section{A.2. $L A-I C P-M S$}

The laser ablation-ICP-MS method (LA-ICPMS) has been developed to yield reliable $\mathrm{U}-\mathrm{Pb}$ ages on zircon and monazite on a routine basis at the Department of Geology, Universidade Federal de Ouro Preto, Brazil. The analyses were performed using an Agilent 7700 Q-ICP-MS and a $213 \mathrm{~nm}$ New Wave laser. Operating conditions were optimized to provide maximum sensitivity for the high masses (207Pb and 238U) while inhibiting oxide formation $(\mathrm{ThO}+/ \mathrm{Th}+<1.0 \%)$. The standard and unknown zircons were ablated in small volume (tear-drop shape) sample cell, with an insert that holds one 25-mm-diametre sample mount and a 7-mm-diametre standard mount. Acquisitions consisted of a 20 s measurement of the gas blank, followed by 40 s measurement of $\mathrm{U}$, Th and $\mathrm{Pb}$ signals during ablation, and $30 \mathrm{~s}$ washout (e.g., Lana et al., 2010; Buick et al., 2011). Samples, standards and sample holders were acid-washed before being analyzed to remove possible surface $\mathrm{Pb}$ contamination. Laser ablations were performed at $40 \mu \mathrm{m}$ spot size, $\sim 6-8 \mathrm{~J} / \mathrm{cm}^{2}$ fluence and $10 \mathrm{~Hz}$ repetition rate. Ablations occurred in a He carrier gas, and the resulting aerosol was mixed with Ar prior to introduction into the ICP-MS via $4 \mathrm{~mm}$ Tygontubing (pre-cleaned with $1 \%$ ultra-pure nitric acid). Integration times were $15 \mathrm{~ms}$ for ${ }^{206} \mathrm{~Pb} ; 40 \mathrm{~ms}$ for ${ }^{207} \mathrm{~Pb}$ and $10 \mathrm{~ms}$ for ${ }^{208} \mathrm{~Pb} ;{ }^{204} \mathrm{~Pb}+\mathrm{Hg} ;{ }^{232} \mathrm{Th},{ }^{238} \mathrm{U}$.

The relevant isotopic ratios $\left({ }^{207} \mathrm{~Pb} /{ }^{206} \mathrm{~Pb},{ }^{208} \mathrm{~Pb} /{ }^{206} \mathrm{~Pb}\right.$, ${ }^{208} \mathrm{~Pb} /{ }^{232} \mathrm{Th},{ }^{206} \mathrm{~Pb} /{ }^{238} \mathrm{U}$ and ${ }^{207} \mathrm{~Pb} /{ }^{235} \mathrm{U}$, where ${ }^{235} \mathrm{U}$ was calculated from ${ }^{238} \mathrm{U}$ counts via the natural abundance ratio $\left.{ }^{235} U={ }^{238} U / 137.88\right)$ have been calculated using the data reduction software Glitter (Van Achterbergh et al., 2001). Individual isotopic ratios were displayed in time-resolved mode. For our laser system, isotopic ratios generated during the first $5 \mathrm{~s}$ of each analysis were discarded. The integration window for the remainder of each analysis was chosen to exclude signal segments that were related to zones of $\mathrm{Pb}$ loss (e.g., fractures), high common $\mathrm{Pb}$ (as recognized by ${ }^{204} \mathrm{~Pb}+\mathrm{Hg}$ counts markedly higher than the high background caused by ${ }^{204} \mathrm{Hg}$ contamination) or $\mathrm{Pb}$ inheritance. Instrumental drift was corrected against the zircon standard using linear interpolative fits. Calibrations were based on six or more analyses of the standard (6-8 analyses of unknowns bracketed between 2 and 3 analyses of standards). ${ }^{204} \mathrm{~Pb}$-based common $\mathrm{Pb}$ corrections were not applied.

Two secondary standards were used during runs: Plesovice zircon (337 $\pm 1 \mathrm{Ma}$; Sláma et al., 2008) and M125 zircon (524 $\pm 1 \mathrm{Ma}$; Klotzli et al., 2009). Sixty-two analyses of Plesovice zircon std gave a Concordia age of $338 \pm 1 \mathrm{Ma}\left(\right.$ mean ${ }^{207} \mathrm{~Pb} /{ }^{206} \mathrm{U}$ age $=337 \pm 8$; mean ${ }^{206} \mathrm{~Pb} /{ }^{238} \mathrm{U}$ age $=338 \pm 1 ;$ mean ${ }^{207} \mathrm{~Pb} /{ }^{235} \mathrm{U}$ age $\left.=338 \pm 1 \mathrm{Ma}\right)$. Fifty-two analyses of the M125 zircon std gave a Concordia age of $526 \pm 1 \mathrm{Ma}$ (mean ${ }^{207} \mathrm{~Pb} /{ }^{206} \mathrm{U}$ age $=525 \pm 7$; mean ${ }^{206} \mathrm{~Pb} /{ }^{238} \mathrm{U}$ age $=526 \pm 1$; mean ${ }^{207} \mathrm{~Pb} / 235 \mathrm{U}$ age $526 \pm 1 \mathrm{Ma}$ ). See supplementary data for detailed information about the individual analyses and "within run" ages obtained for these zircon standards. In order to constraint the reproducibility of the instrument for Archaean zircons we tested zircon grains from an Archaean tonalite (Kaap Valley Tonalite) which record a TIMS age of $3227 \pm 1$ Ma (Kamo and Davis, 1994). Zircons from this sample were analyzed at the end of two sections (Day 3 and Day 6). The analyses yielded concordant andsubconcordant points as expected for this rock (e.g., Armstrong et al., 1990; Kamo and Davis, 1994; Schoene et al., 2008). The obtained $\mathrm{Pb}$ loss discordia for all 42 points (Day $3+$ Day 6 ) gave an upper intercept age of $3227 \pm 3 \mathrm{Ma}(\mathrm{MSDW}=0.99)$ and a lower intercept age of $447 \pm 150 \mathrm{Ma}$.

\section{Electronic supplement}

Compiled tables of SHRIMP and LA-ICP-MS analyses. The excel file includes data for individual samples and three secondary standards.

\section{Appendix B. Supplementary data}

Supplementary data associated with this article can be found, in the online version, at http://dx.doi.org/10.1016/ j.precamres.2013.03.008.

\section{References}

Alkmim, F.F., Marshak, S., 1998. The Transamazonian orogeny in the Quadrilátero Ferrífero, Minas Gerais, Brazil: Paleoproterozoic Collision and Collapse in the Souhtern São Francisco Craton region. Precambrian Research 90, 29-58.

Alkmim, F.F., Marshak, S., Pedrosa-Soares, A.C., Peres, G.G., Cruz, S., Whittington, A., 2006. Kinematic evolution of the Araçuaí-West Congo orogen in Brazil and Africa: Nutcracker tectonics during the Neoproterozoic assembly of Gondwana. Precambrian Research 149, 43-64.

Alkmim, F.F., Martins-Neto, M.A., 2012. Proterozoic first-order sedimentary sequences of the São Francisco Craton, eastern Brazil. Marine and Petroleum Geology 33, 127-139.

Almeida, F.F.M., Hasui, Y., Brito Neves, B.B., Fuck, R.A., 1981. Brazilian structural provinces: an introduction. Earth Sciences Reviews 17, 1-29.

Anhaeusser, C.R., 1969. The Stratigraphy, Structure and Gold Mineralization of the Jamestown and Sheba Hills Area of the Barberton Mountain Land. Ph.D. Thesis, University of the Witwatersrand, Johannesburg, South Africa, 322pp.

Anhaeusser, C.R., 1984. Structural elements of Archaean granite-greenstone terranes as exemplified by the Barberton Mountain Land, South Africa. In: Kroener, A., Greiling, R. (Eds.), Precambrian Tectonics Illustrated. E. Schweizerbart'sche Verlagsbuchhandlung. Stuttgart, Germany, p. 419.

Armstrong, R.A., Compston, W., de Wit, M.J., Williams, I.S., 1990. The stratigraphy of the 3.5-3.2 Ga Barberton Greenstone Belt revisited: a single zircon ion microprobe study. Earth and Planetary Sciences Letters 101, 90-106.

Baltazar, O.F., Zucchetti, M., 2007. Lithofacies associations and structural evolution of the Archean Rio das Velhas greenstone belt, Quadrilátero Ferrífero, Brazil: a review of the setting of gold deposits. Ore Geology Reviews 32,1-2.

Bédard, J.H., 2006. A catalytic delamination-driven model for coupled genesis of Archaean crust and sub-continental lithospheric mantle. Geochimica et Cosmochimica Acta 70, 1188-1214.

Babinski, M., Chemale Jr., F., Van Schmus, W.R., 1995. The $\mathrm{Pb} / \mathrm{Pb}$ age of the Minas Supergoup carbonate rocks, Quadrilátero Ferrífero, Brazil. Precambrian Research 72, 235-245.

Black, L.P., Kamo, S.L., Allen, C.M., Aleinikoff, J.N., Davis, D.W., Korsch, R.J., Foudoulis, C., 2003. TEMORA 1: a new zircon standard for Phanerozoic U-Pb geochronology. Chemical Geology 200, 155-170.

Buick, I.S., Lana, C., Gregory, C., 2011. A LA-ICP-MS and SHRIMP U/Pb age constraint on the timing of REE mineralisation associated with Bushveld granites. South African Journal of Geology 144, 1-14.

Campos, J.C.S., Carneiro, M.A., Basei, M.A.S., 2003. U-Pb evidence for Neoarchean crustal reworking in southern São Francisco Craton (Minas Gerais, Brazil). Anais da Academia Brasileira de Ciências 75, 497-511.

Carneiro, M.A., 1992. O Complexo Metamórfico Bonfim Setentrional (Quadrilátero Ferrífero, Minas Gerais): Litoestratigrafia e evolução geológica de um segmento de crosta continental do Arqueano. Unpublished PhD Thesis, University of São Paulo, Brazil, 233p.

Carneiro, M.A., Jordt-Evangelista, H., Teixeira, W., 1997. Eventos magmáticos arqueanos de natureza cálcio-alcalina e tholeíitica no Quadrilátero Ferrífero e suas implicações tectônicas. Revista Brasileira de Geociências 27, 121-128.

De Wit, M.J., 1998. On Archean granites, greenstones, Cratons and tectonics: does the evidence demand a verdict? Precambrian Research 91, 181-226.

De Wit, M.J., Roering, C., Hart, R.J., Armstrong, R.A., De Ronde, C.E.J., Green, R.W.E., Tredoux, M., Peberdy, E., Hart, R.A., 1992. Formation of an Archean continent. Nature 357, 553-562.

De Ronde, C.E.J., De Wit, M.J., 1994. Tectonic history of the Barberton greenstonebelt, South Africa: 490 million years of Archean crustal evolution. Tectonics 13, 983-1015.

De Ronde, C.E.J., Kamo, S.L., 2000. An Archaean arc-arc collisional event: a shortlived (ca. 3Myr) episode, Weltevreden area, Barberton greenstone belt, South Africa. Journal of African Earth Science 30, 219-248. 
Dorr II, J.V.N., Gair, J.E., Pomerene, J.G., Rynearson, G.A., 1957. Revisão da estratigrafia pré-cambriana do Quadrilátero Ferrífero. DNPM-DFPM, Rio de Janeiro, 31p.

Dorr II, J.V.N., 1969. Physiographic, Stratigraphic and Structural Development of the Quadrilátero Ferrífero, Minas Gerais, Brazil. USGS/DNPM, Washington, Prof. Paper 641-A, 110p.

Endo, I., 1997. Regimes tectônicos do Arqueano e Proterozóico no interior da Placa Sanfranciscana: Quadrilatero Ferrífero e áreas adjacentes, Minas Gerais. Unpublished PhD Thesis, University of São Paulo, Brazil, 330p.

Foley, S., Tiepolo, M., Vannucci, R., 2002. Growth of early continental crust controlled by melting of amphibolite in subduction zones. Nature 417, 837-840.

Hartmann, L.A., Endo, I., Suita, M.T.F. Santos, J.O.S., Frantz, J.C., Carneiro, M.A., Naughton, N.J., Barley, M.E., 2006. Provenance and age delimitation of Quadrilátero Ferrífero sandstones based on zircon $\mathrm{U}-\mathrm{Pb}$ isotopes. Journal of South American Earth Sciences 20, 273-285.

Kamo, S.L., Davis, D.W., 1994. Reassessment of Archean crustal development in the Barberton Mountain Land, South Africa, based on U-Pb dating. Tectonics 13, 167-192.

Klotzli, U., Klotzli, E., Gunes, Z., Kosler, J., 2009. Accuracy of laser ablation U-Pb zircon dating: results from a test using five different reference zircons. Geostandards and Geoanalytical Research 33, 5-15.

Kisters, A.F.M., Belcher, R.W., Poujol, M., Dziggel, A., 2010. Continental growth and convergence-related arc plutonism in the Mesoarchaean: evidence from the Barberton granitoid-greenstone terrain, South Africa. Precambrian Research 178, 15-26.

Kroner, A., Hegner, E., Wendt, J.I., Byerly, G.R., 1996. The oldest part of the Barberton granitoid-greenstone terrain, South Africa, evidence for crust formation between 3.5 and 3.7 Ga. Precambrian Research 78, 105-124.

Kusky, T.M., Polat, A., 1999. Growth of granite-greenstone terranes at convergent margins, and stabilization of Archean Cratons. Tectonophysics 305, $43-73$

Ladeira, E.A., 1980. Metallogenesis of gold at the Morro Velho mine and in the Nova Lima district, Quadrilátero Ferrífero, Minas Gerais.Unpublished PhD Thesis, University of Western Ontario, Canada, 272p.

Lana, C., Kisters, A., Stevens, G., 2010a. Exhumation of MesoArchaean TTG gneisses from the middle crust: insights from the Steynsdorp core complex, Barberton granitoid-greenstone terrain, South Africa. Geological Society of America Bulletin 122, 183-197.

Lana, C., Tohver, E., Cawood, P., 2010b. Quantifying rates of dome-and-keel formation in the Barberton granitoid-greenstone belt, South Africa. Precambrian Research 177, 199-211.

Lana, C., Buick, I., Stevens, G., Rossouw, R., De Wet, W., 2011. 3230-3200 Ma postorogenic extension and mid-crustal magmatism along the southeastern margin of the Barberton Greenstone Belt, South Africa. Journal of Structural Geology 33. $844-858$.

Lowe, D.R., 1994. Accretionary history of the Archean Barberton Greenstone Belt (3.55-3.22 Ga), southern Africa. Geology 22, 1099-1102.

Ludwig, K.R., 2001a. Squid 1.02: A User's Manual. 2. Berkeley Geochronology Centre, Berkeley.

Ludwig, K.R., 2001b. Isoplot/Ex rev.2.49. Berkely Geochronology Centre, Berkely, CA.

Ludwig, K.R., 2003. Isoplot/Ex Version 3.00: a Geochronological Toolkit for Microsoft Excel. Berkeley Geochronology Center, Berkeley, CA.

Machado, N., Carneiro, M.A., 1992. U-Pb evidence of Late Archean tectonothermal activity in southern São Francisco shield, Brazil. Canadian Journal of Earth Sciences 29, 2341-2346.

Machado, N., Noce, C.M., Ladeira, E.A., de Oliveira, O.A.B., 1992. U-Pb geochronology of the Archean magmatism and Proterozoic metamorphism in the Quadrilátero Ferrífero, southern São Francisco Craton, Brazil. Geological Society of America Bulletin 104, 1221-1227.

Machado, N., Schrank, A., Noce, C.M., Gauthier, G., 1996. Ages of detrital zircon from Archean-Paleoproterozoic sequences: Inplications for Greenstone Belt setting evolution of a Transamazonian foreland basin in Quadrilátero Ferrífero, southeast Brazil. Earth and Planetary Science Letters 141, 259-276.

Marshak, S., Alkmim, F.F., Jordt-Evangelista, H., 1992. Proterozoic crustal extension and the generation of dome-and-keel structures in an Archaean granite-greenstone terrane. Nature 357, 491-493.

Martin, H., 1993. The mechanisms of petrogenesis of the Archean continental crust-comparison with modern processes. Lithos 30, 373-388.

Martin, H., 1999. Adakitic magmas: modern analogues of Archaean granitoids. Lithos $46,411-429$.

Moyen, J., Stevens, G., Kisters, A., Belcher, R., 2007. TTG Plutons of the Barberton Granitoid-Greenstone Terrain, South Africa. Developments in Precambrian Geology 15, 607-667.

Noce, C.M., Machado, N., Teixeira, W., 1998. U-Pb geochronology of gneisses and granitoids in the Quadrilátero Ferrífero (Southern São Francisco Craton): age constraints for Archean and Paleoproterozoic magmatism and metamorphism. Revista Brasileira de Geociências 28, 95-102.

Noce, C.M., 1995. Geocronologia dos eventos magmáticos, sedimentares e metamórficos na região do Quadrilátero Ferrífero, Minas Gerais. Unpublished PhD Theses, University of São Paulo, Brazil, 129 p.

Noce, C.M., Zucchetti, M., Baltazar, O.F., Armstrong, R., Dantas, E.L., Renger, F.E., Lobato, L.M., 2005. Age of felsic volcanism and the role of ancient continental crust in the evolution of the Neoarchean Rio das Velhas greenstone belt (Quadrilátero Ferrífero, Brazil): U-Pb zircon dating of volcaniclastic graywackes. Precambrian Research 141, 67-82.
Noce, C.M., Pedrosa-Soares, A.C., Silva, L.C., Armstrong, R., Piuzana, D., 2007. Evolution of polycyclic basement in the Araçuaí Orogen, based on U-Pb SHRIMP data: implications for the Brazil-Africa links in the Paleoproterozoic time. Precambrian Research 159, 60-78.

Nutman, A.P., Friend, C.R.L., Baadsgaard, H., McGregor, V.R., 1989. Evolution and assembly of Archean gneiss terranes in the Godthåbsfjord region, southern west Greenland: structural, metamorphic, and isotopic evidence. Tectonics 8, 573-589.

Nutman, A.P., Friend, C.R.L., Bennett, V.C., 2002. Evidence for 3650-3600 Ma assembly of the northern end of the Itsaq Gneiss Complex Greenland: implication for early Archaean tectonics. Tectonics 21, http://dx.doi.org/10.1029/2000TC001203.

Pedrosa-Soares, A.C., Noce, C.M., Wiedemann, C.M., Pinto, C.P., 2001. The AraçuaíWest Congo orogen in Brazil: An overview of a confined orogen formed during Gondwanland assembly. Precambrian Research 110, 307-323.

Percival, J.A., Stern, R.A., Skulski, T., 2001. Crustal growth through successive arc magmatism, northeastern Superior Province, Canada. Precambrian Research 109, 203-238.

Percival, J.A., Stern, R.A., Skulski, T., Card, K.D., Mortensen, J.K., Bégin, N.J., 1994. Minto Block, Superior Province-missing link in deciphering assembly of the Craton at $2.7 \mathrm{Ga}$. Geology 22, 839-842.

Rapp, R.P., Shimizu, N., Norman, M.D., 2003. Growth of early continental crust by partial melting of eclogite. Nature 425, 605-609.

Renger, F.E., Noce, C.M., Romano, A.W., Machado, N., 1995. Evolução sedimentar do Supergrupo Minas: 500 Ma. de registro geológico no Quadrilátero Ferrífero, Minas Gerais, Brasil. Geonomos 2 (1), 1-11.

Romano, A.W., 1989. Evolution tectonique de la région NW du Quadrilatère Ferrifère - MinasGerais, Brésil. Unpublished PhD Thesis, University of Nancy, France, 259p.

Romano, R., Lana, C., Alkmim, F.F., Stevens, G.S., Armstrong, R., 2013. Stabilization o the southern portion of the São Francisco Craton, SE Brazil, through a long-lived period of potassic magmatism. Precambrian Research 224, 143-159.

Schoene, B., De Wit, M.J., Bowring, S.A., 2008. MesoArchaean assembly and stabilization of the eastern Kaapvaal Craton. A structural-thermochronologica perspective. Tectonics 27, 1-27.

Schoene, B., Duda, F.O., De Wit, M.J., Bowring, S.A., 2009. Sm-Nd isotopic mapping of lithospheric growth and stabilization in the eastern Kaapvaal Craton. Terra Nova 21, 219-228.

Schrank, A., Souza Filho, C.R., Roig, H.L., 1990. Novas Observações sobre as Rochas Ultramáficas do Grupo Quebra Osso e Formação Córrego dos Boiadeiros, Greenstone Belt Rio Velhas - MG. Cadernos Instituto de Geociências/UNICAMP 1 $6-29$.

Seixas, L.A.R., David, J., Stevenson, R., 2012. Geochemistry, Nd isotopes and U-Pb geochronology of a 2350 Ma TTG suite, Minas Gerais, Brazil: implications for the crustal evolution of the southern São Francisco craton. Precambrian Research 196, 61-80.

Sircombe, K.N., 2004. Age display: an EXCEL workbook to evaluate and display univariate geochronological data using binned frequency histograms and probability density distributions. Computers and Geoscience 30, 21-31.

Sláma, J., Košler, J., Condon, D.J., Crowley, J.L., Gerdes, A., Hanchar, J.M., Horstwood, M.S.A., Morris, G.A., Nasdala, L., Norberg, N., Schaltegger, U., Schoene, B., Tubrett M.N., Whitehouse, M.J., 2008. Plešovice zircon-a new natural reference material for U-Pb and $\mathrm{Hf}$ isotopic microanalysis. Chemical Geology 249, 1-35.

Smithies, R.H., Champion, D.C., Cassidy, K.F., 2003. Formation of Earth's early Archaean continental crust. Precambrian Research 127, 89-101.

Smithies, R.H., Champion, D.C., Van Kranendonk, M.J., Howard, H.M., Hickman, A.H. 2005. Modern-style subduction processes in the Mesoarchaean: geochemical evidence from the $3.12 \mathrm{Ga}$ Whundo intraoceanic arc. Earth and Planetary Science Letters 231, 221-237.

Stacey, J.S., Kramers, J.D., 1975. Approximation of terrestrial lead isotope evolution by a 2-stage model. Earth and Planetary Science Letters 26, 207221.

Steiger, R.H., Jäger, E., 1977. Subcommission on geochronology: convention on the use of decay constants in geo- and cosmochronology. Earth and Planetary Science Letters 36, 359-362.

Stott, G., Mueller, W., 2009. Superior Province: the nature and evolution of the Archean continental lithosphere. Precambrian Research 168, 1-3.

Teixeira, W., Figueiredo, M.C.H., 1991. An outline of Early Proterozoic crustal evolution in the São Francisco Craton. Brazil: a review. Precambrian Research 53, $1-22$.

Teixeira, W., Carneiro, M.A., Noce, C.A., Machado, N., Sato, K., Taylor, P.N., 1996 $\mathrm{Pb}, \mathrm{Sr}$ and $\mathrm{Nd}$ isotope constraints on the archean evolution of gneissic granitoid complexes in the southern São Francisco Craton, Brazil. Precambrian Research 78, 151-164.

Teixeira, W., Sabaté, P., Barbosa, J., Noce, C.M., Carneiro, M.A., 2000. Archean and Paleoproterzoic tectonic evolution of the São Francisco Craton, Brazil. In: Cordani, U.G., Milani, E.J., Thomaz Fo, A., Campos, D.A. (Eds.), Tectonic Evolution of South América. Rio de Janeiro, 31st International Geological Congress. Rio de Janeiro, pp. 101-137.

Teixeira, W., Ávila, C.A., Nunes, L.C., 2008. Nd-Sr isotopic geochemistry and U-Pb geochronology of the Fé Granite Gneiss and Lajedo Granodiorite: implication for the Paleoproterozoic Evolution of the Mineiro belt, southern São Francisco Craton, Brazil. Revista do Instituto de Geociências-USP, Série Científica 8, 53-74

van Achterbergh, E., Ryan, C.G. Jackson, S.E, Griffin, W, 2001. Data reduction software for LA-ICP-MS. In: Sylvester, P. (Ed.), Laser Ablation ICPMS in the Earth Science, vol. 29. Mineralogical Association of Canada, pp. 239-243. 
Williams, I.S., Claesson, S., 1987. Isotopic evidence for the Precambrian provenance and Caledonian metamorphism of high grade paragneisses from the Seve Nappes, Scandinavian Caledonides. II. Ion microprobe zircon U-Th-Pb. Contributions to Mineralogy and Petrology 97, 205-217.

Windley, B.F., Garde, A.A., 2009. Arc-generated blocks with crustal sections in the North Atlantic Craton of West Greenland: crustal growth in the Archean with modern analogues. Earth-Science Reviews 93, 1-30.
Zucchetti, M., Lobato, L.M., Baltazar, O.F., 2000a. Volcanic and volcaniclastic features in Archean rocks and their tectonic environment, Rio das Velhas Greenstone Belt, Quadrilátero Ferrífero, MG. Brazil. Revista Brasileira de Geociências 30, 388-392.

Zucchetti, M., Lobato, L.M., Baars, F.J., 2000b. Genetically diverse basalt geochemical signatures developed in the Rio das Velhas Greenstone Belt, Quadrilátero Ferrífero, Minas Gerais, Brazil. Revista Brasileira de Geociências 30, 397-402. 